\title{
U.S. GEOLOGICAL SURVEY WATER-RESOURCES PROGRAMS IN THE NEW YORK DISTRICT — FISCAL YEARS 1993-94
}

Compiled by Mary Patricia Lee

\section{U.S. GEOLOGICAL SURVEY}

Open-File Report 96-113

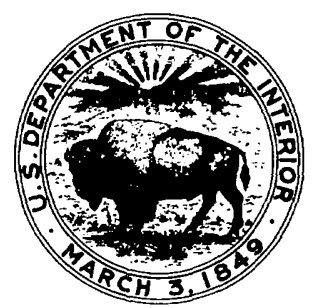

Troy, New York 1996 


\title{
DEPARTMENT OF THE INTERIOR
}

\author{
BRUCE BABBIT, Secretary
}

U. S. GEOLOGICAL SURVEY

Gordon P. Eaton, Director

For additional information write to:

Copies of this report may be purchased from:

District Chief

U. S. Geological Survey 425 Jordan Rd.

Troy, NY 12180
U.S. Geological Survey ESIC-Open-File Reports Section Box 25286

Denver, CO. 80225 


\section{CONTENTS}

Introduction $\mathbf{1}$

U.S. Geological Survey programs 1

Water Resources Division's mission and program 2

Types of funding $\mathbf{3}$

Cooperating agencies in 19944

New York District 6

Projects in 1993-94 9

Troy OFFICE PROJECTS

001 Surface-water stations $\mathbf{1 0}$

002 Ground-water stations 11

003 Water-quality stations 12

005 National Trends Network (NTN) 13

007 Water-use data 14

045 Flood investigations 15

046 PCB transport in the upper Hudson River 16

114 Hydrogeologic assessment of selected aquifers 17

152 Long-term monitoring of streams in Catskill Mountains 18

178 Evaluation of scour at bridges in New York 19

191 Water-resources, data-collection and monitoring network in the Croton watershed 20

192 Ground-water resources of the Batavia Kill 21

199 National Water-Quality Assessment of the Hudson River basin 22

200 Stream-water quality as a function of watershed scale $\mathbf{2 3}$

204 Biogeochemical processes that control nitrogen cycling 24

206 PCB and Trace Metals in Lake Champlain 25

208 Aluminum and calcium chemistry in Red Spruce forests 26

209 Variable Source-area control of episodic stream chemistry 27

ITHACA OFFICE PROJECTS

184 Contributing areas and contaminant sources to ground-water supply in Cortland 28

186 Probabilistic assessment of atrazine contamination 29

190 Effects of stormwater detention in wetlands of lower Irondequoit $\mathbf{3 0}$

205 Hydrogeology of the Tully Valley Mudboils 31

207 Use of wetland systems to treat leachate $\mathbf{3 2}$ 


\section{CONTENTS}

(continued)

Coram OFFICE PROJECTS

180 Northeast Atlantic Coastal Plain ground-water quality $\mathbf{3 3}$

182 Modifications of recharge structures 34

196 Iron in the Long Island ground-water system $\mathbf{3 5}$

202 Geohydrology of northern Nassau County 36

203 Aquifers inKings and Queens Counties $\mathbf{3 7}$

300 Human Activities and Water Quality $\mathbf{3 8}$

301 Evaluation of the Hydrogeologic System at Brookhaven National Laboratory

302 Determination of Discharge to the Peconic Estuary System 40

305 National Water-Quality Assessment of Long-Island-New Jersey 41

New York District staff $\mathbf{4 2}$

Reports published or released, October 1992-September $1994 \quad 43$

Sources of U. S. Geological Survey publications $\mathbf{4 7}$

Additional sources of information on programs in New York 48

\section{ILLUSTRATIONS}

Figure 1.-Organization chart and list of office addresses 7

Figure 2.-Map showing counties in New York State and locations of USGS offices 8 


\section{INTRODUCTION}

The U.S. Geological Survey (USGS) was established by an act of Congress on March 3, 187?, to provide a permanent Federal Agency to conduct the systematic and scientific "classification of th? public lands, and examination of the geologic structure, mineral resources, and products of nationsl domain." An integral part of that original mission includes publishing and disseminating the eartr. science information needed to understand, to plan the use of, and to manage the Nations's energy, land, mineral, and water resources.

\section{U.S. Geological Survey Programs}

Since 1879, the research and fact-finding role of the USGS has grown and been modified to meet the changing needs of the Nations it serves. As part of that evolution, the USGS has become the Federal Government's largest earth-science agency, the Nation's largest civilian mapmaking agency, the Nation's largest water research and water information agency, the primary source of data on the Nation's surface-water and ground-water resources, and the employer of the largest number of professional earth scientists. Today's programs serve a diversity of needs and users. Programs include:

- Conducting detailed assessments of the energy and mineral potential of the Nation's land and offshore areas.

- Investigating and issuing warnings of earthquakes, volcanic eruptions, landslides, and other geologic and hydrologic hazards.

- Conducting research on the geologic structure of the Nation.

- Studying the geologic features, structure, processes, and history of the other planets of our solar system.

- Conducting topographic surveys of the Nation and preparing topographic and thematic maps and related cartographic products.

- Developing and producing digital cartographic data bases and products.

- Collecting data on a routine basis to determine the quantity, quality, and use of surface water and ground water.

- Conducting water-resource appraisals to describe the consequences of alternative plans for developing land and water resources.

- Conducting research in hydraulics and hydrology, and coordinating all Federal water-data acquisition.

- Using remotely-sensed date to develop new cartographic, geologic, and hydrologic research techniques for natural resources planning and management.

- Providing earth-science information through an extensive publications program and a network of public access points. 
Along with its continuing commitment to meet the growing and changing earth-science needs of the Nation, the USGS remains dedicated to its original mission to collect, analyze, interpret, publish, and disseminate information about the natural resources of the Nationproviding "Earth Science in the Public Service."

\section{Water-Resources Division's Mission and Program}

The mission of the Water Resources Division is to provide the hydrologic information and understanding needed for the optimum use and management of the Nation's water resources for the overall benefit of the people of the United States. This is accomplished, in large part, through cooperation with other Federal and non-Federal agencies by:

- Collecting, on a systematic basis, data needed for the continuing determination and evaluation of the quantity, quality, and use of the Nation's water resources.

- Conducting analytical and interpretive water-resource appraisals describing occurrence, availability, and the physical, chemical and biological characteristics of surface water and ground water.

- Conducting supportive basic and problem-oriented research in hydraulics, hydrology, and related fields of science to improve the scientific basis for investigations and measurement techniques and to understand hydrologic systems sufficiently well to quantitatively predict their response to stress, either natural or manmade.

- Disseminating the water data and the results of these investigations and research through reports, maps, computerized information services, and other forms of public releases.

- Coordinating the activities of Federal agencies in the acquisition of water data for streams, lakes, reservoirs, estuaries, and ground water.

- Providing scientific and technical assistance in hydrologic fields to other Federal, State, and local agencies, to licensees of the Federal Power Commission, and to international agencies on behalf of the Department of State. 


\section{Types of Funding}

The diagram below shows the percentage of the investigations for fiscal year 1994 in each of the broad categories of collection of hydrologic data, areal appraisals and interpretive studies, and research projects:

FY 94

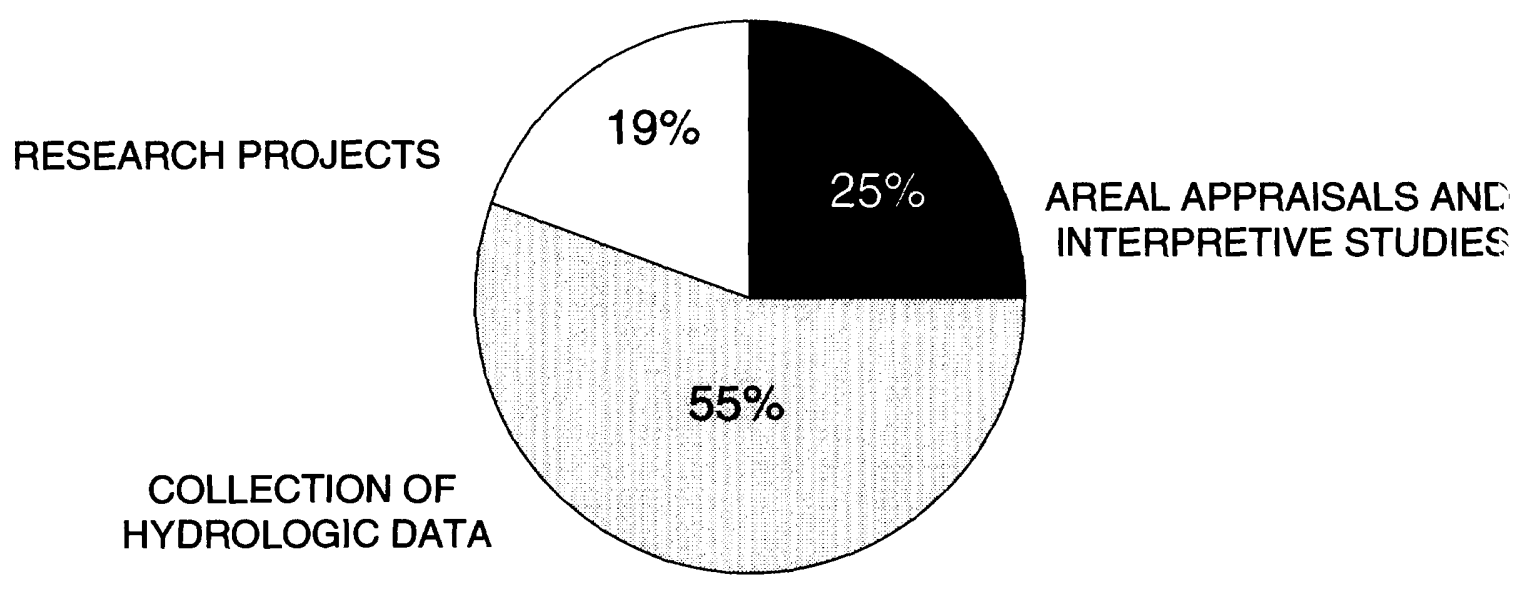

These investigations are directed toward obtaining the information needed by managers and planners for the solution or alleviation of water problems in New York. The investigations are supported by funds provided by State and local units of government and federal funds from the U.S. Geological Survey and other federal agencies. About 75 percent of the federal funds contributed by the U.S. Geological Survey are used to match, up to a 50-50 basis, the funds contributed by the State and other local units of government. In fiscal year 1994, the financial support for all programs in New York was about $\$ 10.4$ million, which was distributed as follows:

FY 94

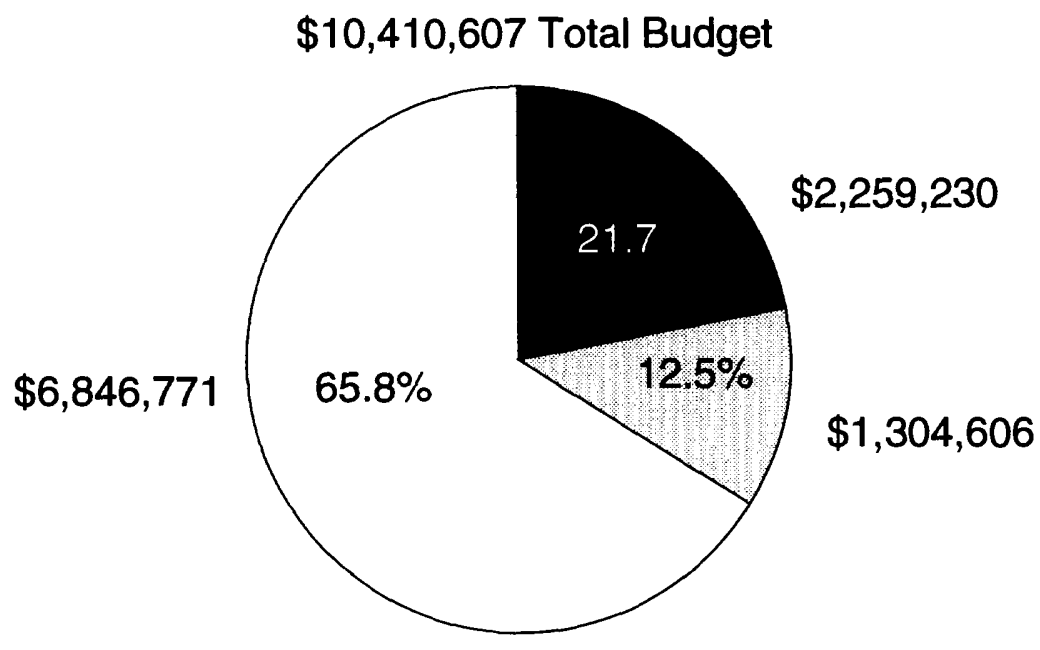




\section{COOPERATING AGENCIES IN FISCAL YEAR 1994}

Chautauqua County, Department of Planning \& Development

City of Auburn

City of Saratoga Springs

City of Syracuse

Clifton Park Water Authority

Cornell University

Erie County

Federal Power Commission

Hudson River-Black River Regulating District

Livingston County Department of Health

Monroe County Department of Environmental Health

Nassau County Department of Public Works

National Oceanic and Atmospheric Administration

New York City Department of Environmental Protection

New York State Department of Environmental Conservation - Division of Water

New York State Department of Transportation

New York State Power Authority

Onondaga County Department of Public Works

Onondaga County Water Authority

Seneca Nation of Indians

State University of New York at Buffalo 


\section{COOPERATING AGENCIES IN FISCAL YEAR 1994 (continued)}

State University of New York at Syracuse

Suffolk County Department of Health Services

Suffolk County Water Authority

Tompkins County Department of Planning

Town of Amherst

Town of Cheektowaga

Ulster County

Ulster County Department of Health

U.S. Air Force - Wright-Patterson Air Force Base

U.S. Army Environmental Center

U.S. Army Corps of Engineers - Buffalo

U.S. Army Corps of Engineers - Pittsburgh

U.S. Department of Agriculture - Forest Service

U.S. Department of Energy - Brookhaven National Laboratory

U.S. Department of Energy - Schenectady Naval Reactors

U.S. Environmental Protection Agency - New York City

U.S. Environmental Protection Agency - Corvallis Environmental Research

U.S. Fish \& Wildlife Service - Montezuma National Wildlife Refuge

Village of Nyack

Village of Victor 


\section{NEW YORK DISTRICT}

The following sections describe the water-resources investigations conducted by the U.S. Geological Survey in New York in fiscal years 1993-94; many of these studies will continue into 1995 or longer. The Geological Survey began its waterresources studies in New York State in 1895 with a stream-gaging program in the Catskill Mountain region and entered its first cooperative program, with the Office. of the State Engineer, in 1900. The Survey has maintained a District office in Albany since 1910 (relocated to Troy in 1995) to direct its water investigations within the State, and a subdistrict office on Long Island since 1932 to study and monitor the ground-water situation in this area of increasing urbanization. The Survey also maintains a subdistrict office in Ithaca, which, in conjunction with the Troy office, collects and interprets data from western and eastern New York, while the Potsdam field office collects records in the northernmost part of the State.

The staff of the New York District numbers about 109. The professional hydrologists represent a variety of scientific and technical backgrounds that incluc's engineering, chemistry, geology, mathematics, physics, biology, and soil science. The hydrologists are assisted by experienced engineering and hydrologic technicians who provide support service in the collection and analysis of field data, and by specialists in computer, publication, and administrative services.

The office addresses and organization chart are on page 7; the office locations are shown in the map below. A partial list of staff members is on page 42 .

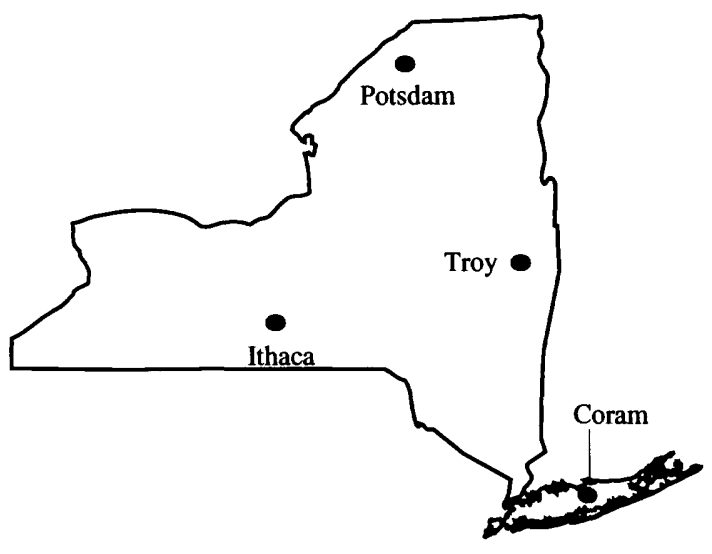




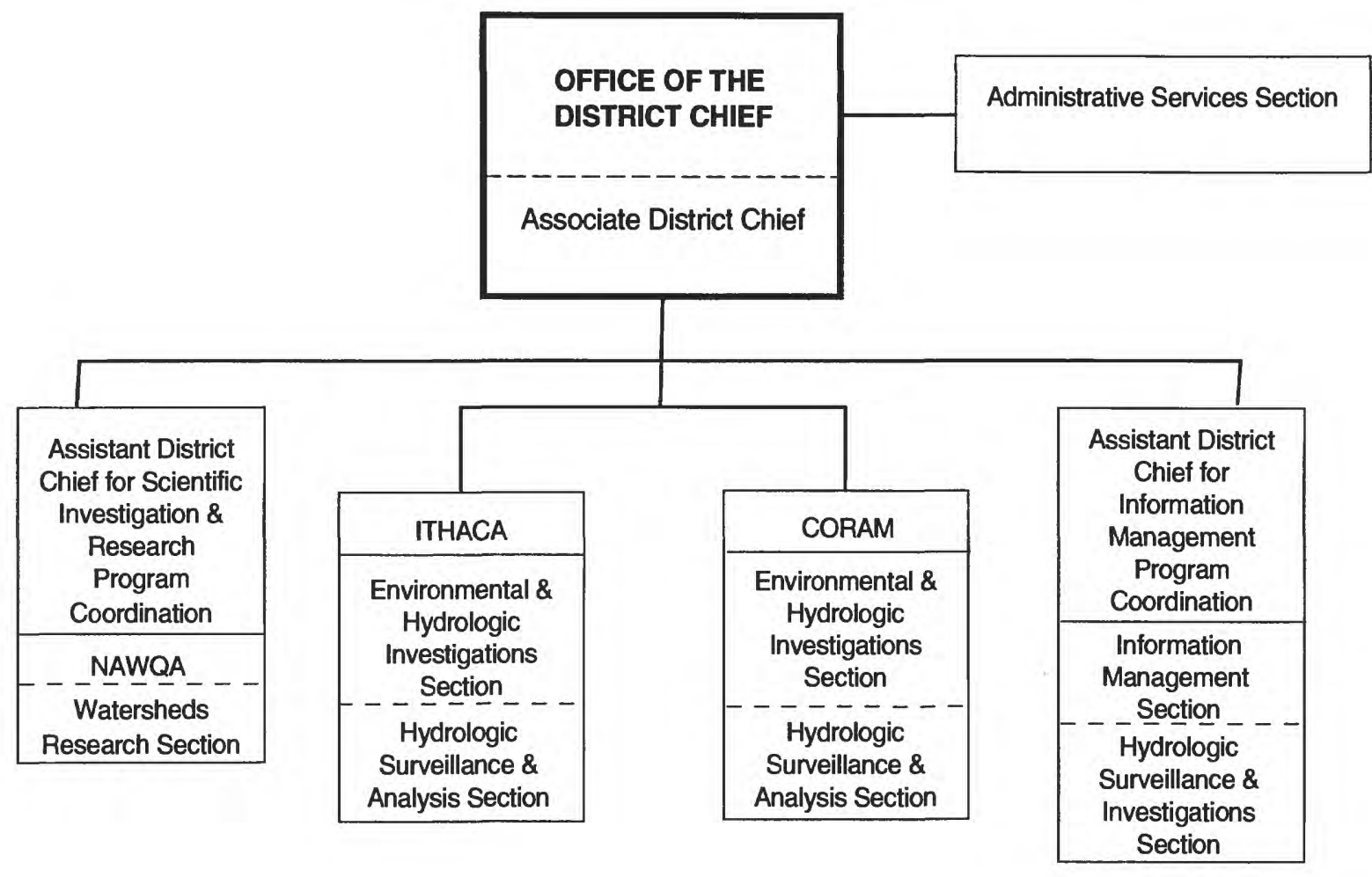

NEW YORK DISTRICT OFFICE ADDRESSES

Troy District Office

Ithaca Subdistrict Office

Coram Subdistrict Office

Potsdam Field Headquarters
(518) $285-5600$

(607) 266-0217

(516) 736-0783

(315) 265-4410
U.S. Geological Survey

Water Resources Division 425 Jordan Rd.

Troy, N.Y. 12180

903 Hanshaw Road

Ithaca, N.Y. 14850-1572

2045 Route 112

Coram. N.Y. 11727

Market Square Mall

22 Depot Street

Box U

Potsdam, N.Y. 13676

Inquiries regarding projects described in this section may be directed to the District Office or Subdistrict Office in which the work originated.

Figure 1.-New York District organization chart with office addresses. (List of staff members is on page 42.) 


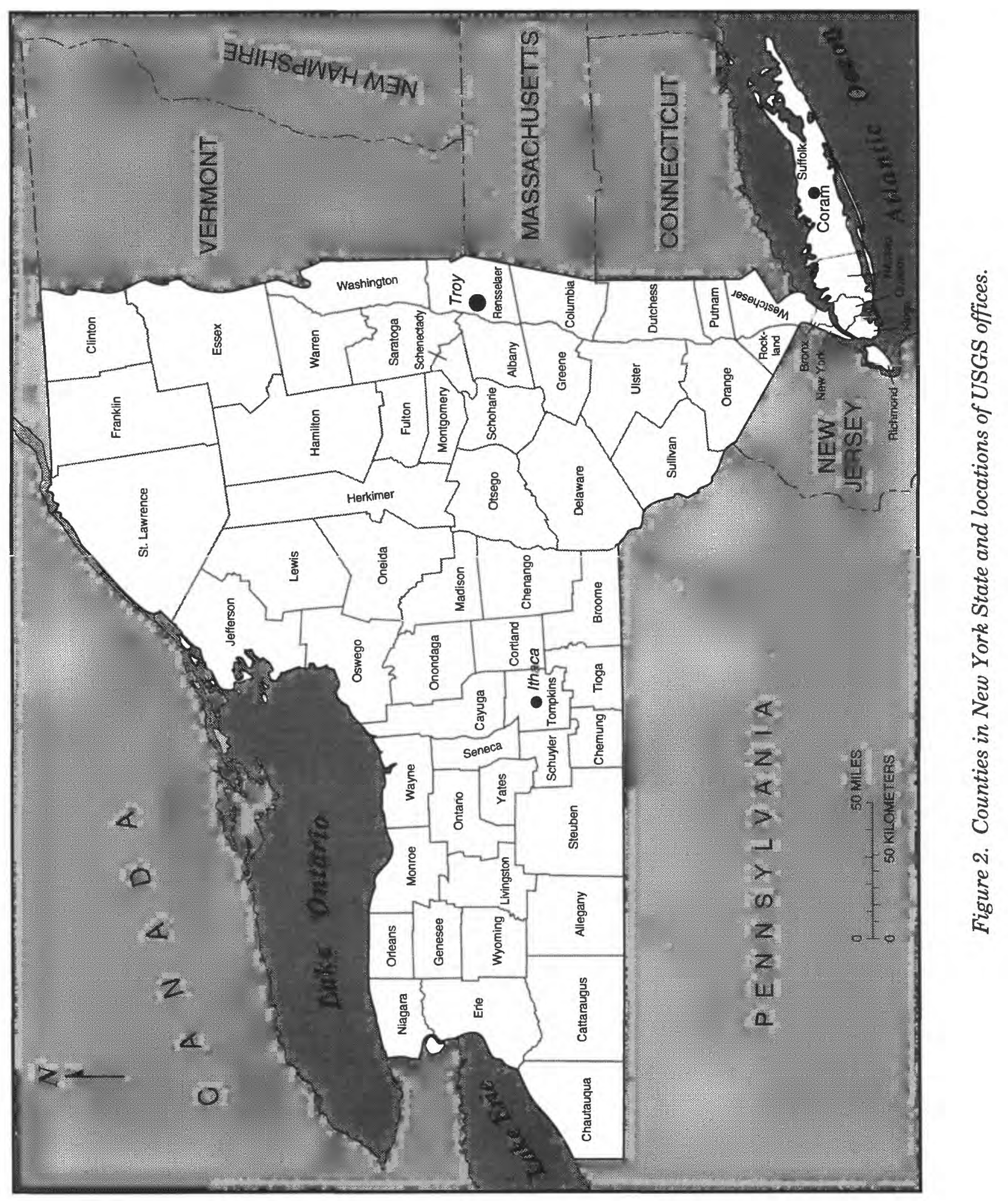




\section{PROJECTS IN FISCAL YEARS 1993-94}

Projects conducted by the New York District during fiscal years 1993-94 are described on the following pages. They are grouped by office location and listed in numerical order by project number. (See list on p. iii-iv.)

$\begin{array}{ll}\text { Troy ........ } & \mathbf{1 0} \\ \text { Ithaca ....... } & \mathbf{2 8} \\ \text { Coram ....... } & \mathbf{3 3}\end{array}$ 


\section{Surface-Water Stations (NY 00-001)}

Period of project: Continuous since June 1898

Project leader: Gary D. Firda

Field location: Statewide

Cooperating agencies: New York State Department of Environmental Conservation; U.S. Army Corps of Engineers; City of New York, Department of Environmental Protection; Nassau County Department of Public Works; Suffolk County Water Authority; National Weather Service; New York Power Authority; County of Chautauqua, Planning Department; Monroe Count, Department of Health; Onondaga County, Department of Drainage and Sanitation; Onondaga County, Water Authority Commission; City of Auburn; Town of Amherst, Erie County; Ulster County, County Legislature; Board of Hudson River-Black River Regulating District; U.S. Department of Energy; Village of Nyack, Rockland County; Village of Victor, Ontario County; City of Sarartoga Springs, Saratoga County; Cornell University.

Problem: Surface-water information is needed for surveillance, planning, design, hazard warning, operation, and management in water-related fields such as water supply, hydroelectric power, flood control, irrigation, bridge and culvert design, wildlife management, pollution abatement, flood-plain management, and waterresources development. An appropriate data base is needed to provide this information.

Objective: (1) To collect surface-water data for (a) assessment of water resources, (b) operation

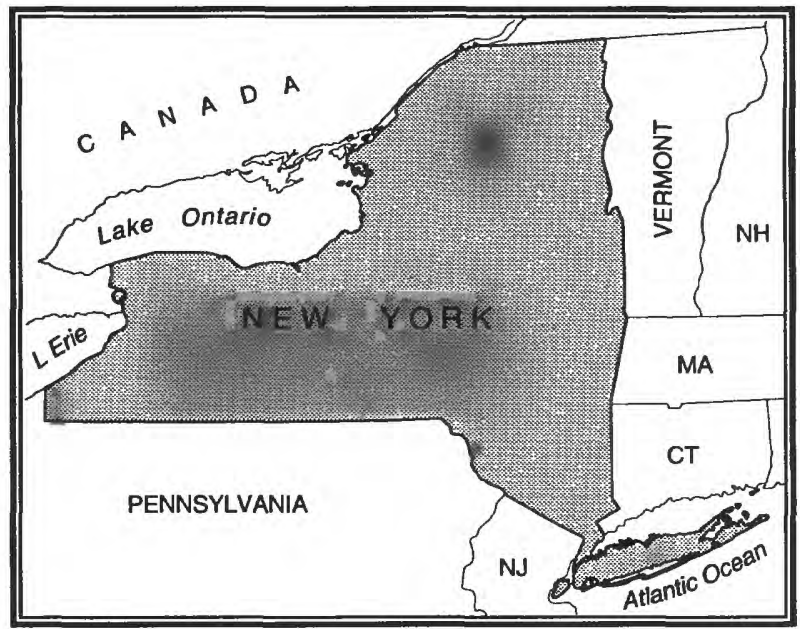

of reservoirs or industries, (c) forecasting of stage or discharge, (d) pollution control and disposal of wastes, (e) providing discharge data to accompany water-quality measurements, (f) compact and legal requirements, and $(\mathrm{g})$ research or special studies. (2) To collect data to define the properties and trends of water in streams, lakes, and estuaries for use in planning and design.

Approach: To use standard methods of data collection as described in the series "Techniques of Water Resources Investigations of the United States Geological Survey" and to use partialrecord gaging instead of continuous-record gaging where possible.

Progress and significant results: Operation of the network continued. Surface-water discharge data were collected at 365 sites. Stageonly data for streams were collected at 7 sites, and stage-only data for lakes and reservoirs were collected at 46 sites. Equipment upgrading at gaging stations continued. New stations, planned through cooperative efforts, were installed in water year 1994.

Plans for next year: To upgrade gaging equipment, and to reactivate and construct specific sites as needed. 


\section{Ground Water Stations (NY 00-002)}

Period of project: Continuous since July 1934

Project leader: John H. Williams

Field location: Statewide

Cooperating agencies: New York State Department of Environmental Conservation; Suffolk County Department of Environmental Control; Suffolk County Water Authority; Nassau County Department of Public Works.

Problem: Long-term information on groundwater levels is needed to evaluate the effects of climatic and manmade stresses on the aquifer systems of New York.

Objectives: (1) To provide long-term waterlevel records from which the response of aquifer systems to climatic and manmade stresses can be evaluated and potential problems can be defined early to allow for proper planning and management. (2) To provide long-term waterlevel records with which short-term information

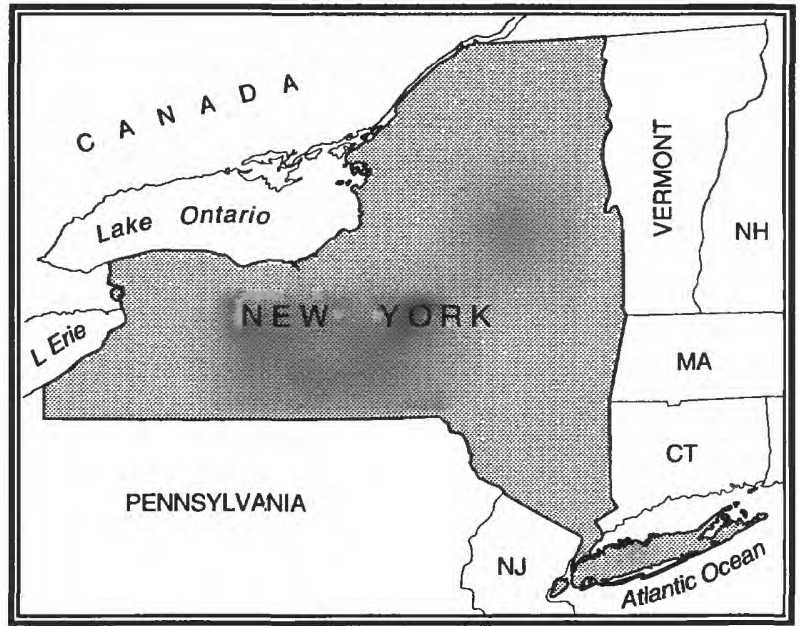

from ground-water investigations can be compared.

Approach: To collect long-term water-level records at selected observation wells that are representative of the hydrologic conditions in the State.

Progress and significant results: Collection and compilation of ground-water levels at $\mathbf{5 0}$ upstate and 800 Long Island wells continued. Ground-water-level records were published in the annual data report.

Plans for next year: To continue to collect, compile, and publish water-level records and evaluate the observation-well network. 


\section{Water-Quality Stations (NY 00-003)}

Period of project: Continuous since June 1906

Project Leader: Kenneth A. Pearsall

\section{Field location: Statewide}

Cooperating agencies: New York State Department of Environmental Conservation; Suffolk County Water Authority; Nassau County Department of Public Works; City of New York, Department of Environmental Protection.

Problem: Water-resources planning and waterquality assessment require statewide and nationwide levels of information on the chemical and physical qualities of surface water and ground water.

Objective: To develop a statewide and nationwide bank of water-quality data for Federal, State, and local planning and to provide these data where needed to support other projects within New York.

Approach: To maintain and operate a statewide network of water-quality stations (some of which are parts of nationwide networks) to provide data on concentrations, loads, and time

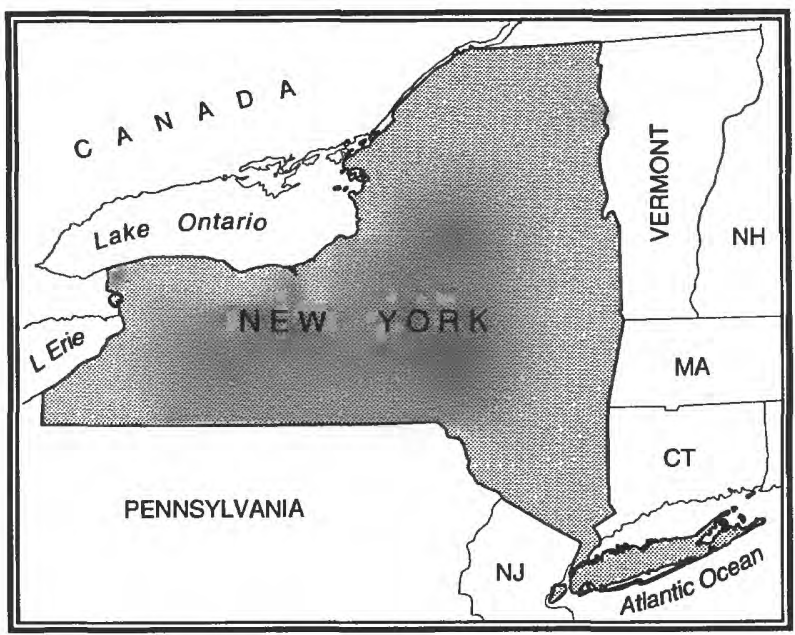

trends of chemical constituents of surface water and ground water, and to provide water-temperature data for management purposes.

Progress and significant results: Water samples were collected at 3 NASQAN (National Stream Quality Accounting Network) stations, one Hydrologic Benchmark Network station, 12 additional surface-water stations, and 32 ground-water stations for chemical analysis. Continuous water-temperature records were collected at 14 stations. Specific conductance and temperature were measured at tide stations, and turbidity was measured at 1 station.

Plans for next year: The collection of waterquality samples will continue at 13 surfacewater stations. Twenty ground-water stations are planned for the network in 1996. Watertemperature and specific-conductance records will be collected at the same stations as in 1994 . Data from 1994 will be published in the annual water-data reports. 


\section{National Trends Network (NTN) For Monitoring Atmospheric DEPOSITION (NY 83-005)}

Period of project: Continuous since June 1983

Project leader: Peter S. Murdoch

Field location: Frost Valley YMCA, Ulster County

Cooperating agency : Federally funded

Problem: A nationwide long-term monitoring network needs to be developed and maintained to detect and measure chemical trends in atmospheric deposition. Before the National Atmospheric Deposition/National Trends Network program began, no national monitoring of deposition chemistry was being done.

Objective: (1) To document weekly variations in atmospheric deposition and collect wet deposition for analysis of elements and compounds that contribute to the chemical composition of surface waters.

Approach: (1) To set up monitoring stations as part of the NTN. (2) To maintain stations, make

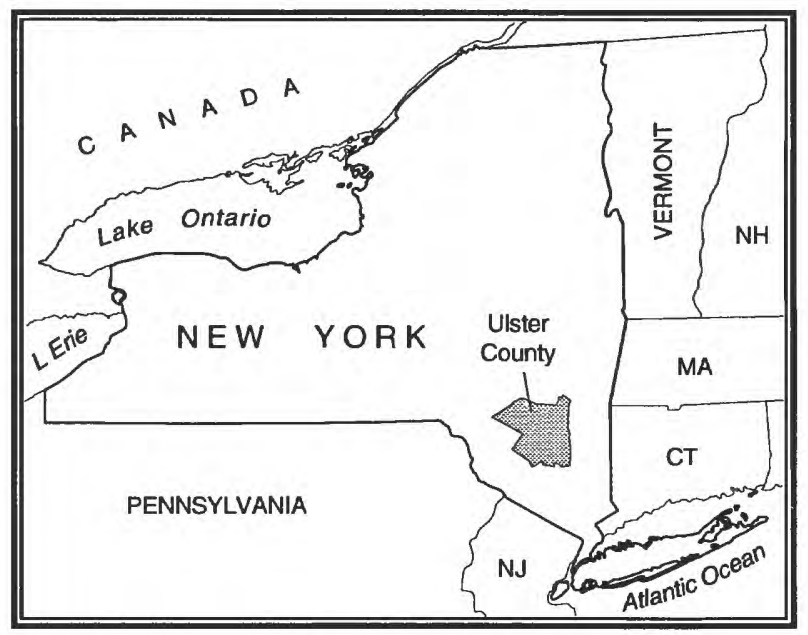

onsite measurements, process samples, and submit samples to laboratories. (3) To verify data retrievals. (4) To prepare a periodic report.

Progress and significant results: Monitoring of volume and chemistry of precipitation and stream water has been continuous since 1983 . Data indicate that the central Catskills receive the largest deposition of sulfate and nitrate in the northeastern United States, that stream sulfate concentrations have been decreasing during the 1980's, and that stream nitrate concentrations have increased significantly over the same period.

Plans for next year: To continue monitoring of precipitation as part of the NTN program. 


\section{NeW York Water-Use Data (NY 79-007)}

Period of project: Continuous since January 1979

Project leader: Deborah S. Snavely Lumia

Field location: Statewide

Cooperating agency: New York State Department of Environmental Conservation

Problem: The demand for water in New York is unevenly distributed, and little information is available on water use. Because increasing competition for local supplies could lead to shortages, information is needed on present uses, how use varies, and how the availability and nature of the resources vary with demand. These are addressed by two studies that are intended to (a) collect data on withdrawal, delivery, and return of water in New York State, and (b) examine the effect of waste disposal sites on water use and availability in Dutchess County.

Objectives: (1) To determine which agencies collect data on water use in specified categories.

(2) To collect and compile water-use data for input to SSWUDS (Site-Specific Water-Use Data System) and AWUDS (Aggregated Water-Use Data System). (3) To develop a system whereby the agencies that collect the data can transmit periodic updates to the main data bank. (4) To make the data available through computer processing and reports. (5) To evaluate the relation between water use and availability in Dutchess County, and identify possible sources of ground-water contamination.

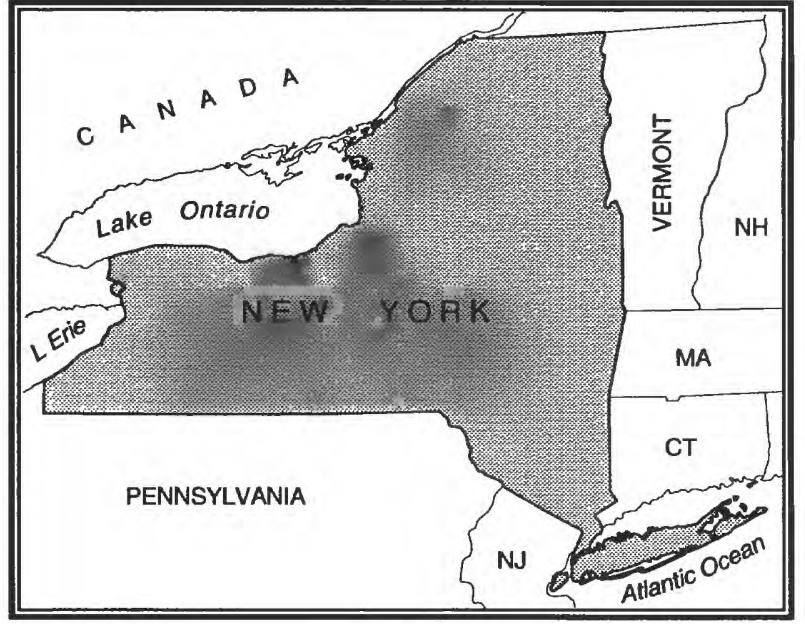

Approach: (1) New York State agencies will furnish water-use data in specific categories of use, and local agencies and organizations in specific counties or drainage basins will also supply water-use data. (2) A system of data transmittal will be established among State and local agencies and the USGS. (3) The data will be used to update SSWUDS and AWUDS. (4) Periodic water-use reports will be written.

Progress and significant results: The Dutchess County report was written and the review process begun. A map report of 1990 statewide water-use data was completed. Documentation on data sources and data-collection methods was begun. An approach for collecting public-water supply data was discussed with the New York State Department of Environmental Conservation.

Plans for next year: (1) To complete the review of the Dutchess County report. (2) To complete the draft water-use report. (3) To complete documentation of methods and sources in New York. (4) To decide which data to collect and update in the public-water-supply category and other categories for the 1995 United States Water-Use Estimate report. 


\section{Flood Investigations (NY 67-045)}

Period of project: Continuous since July 1966

Project leader: Richard Lumia

Field location: Statewide

Cooperating agency: New York State Department of Transportation

Problem: Flooding is a serious problem in many parts of the State. Information on floods and analyses of flood data are needed to aid in the design of bridges, highways, and buildings, and in flood-plain zoning and flood-protection works.

Objective: (1) To provide information on the magnitude and frequency of floods to agencies and individuals involved in flood-protection planning and design. (2) To develop regional flood-frequency relations for the entire State.

(3) To make site studies.

Approach: To (1) collect flood data at creststage stations and publish annual peak discharges; (2) calculate discharges of floods, develop flood profiles, and collect information for flood-plain mapping; (3) prepare reports covering individual floods, and (4) make analyses to improve flood-frequency relations for streams throughout the State.

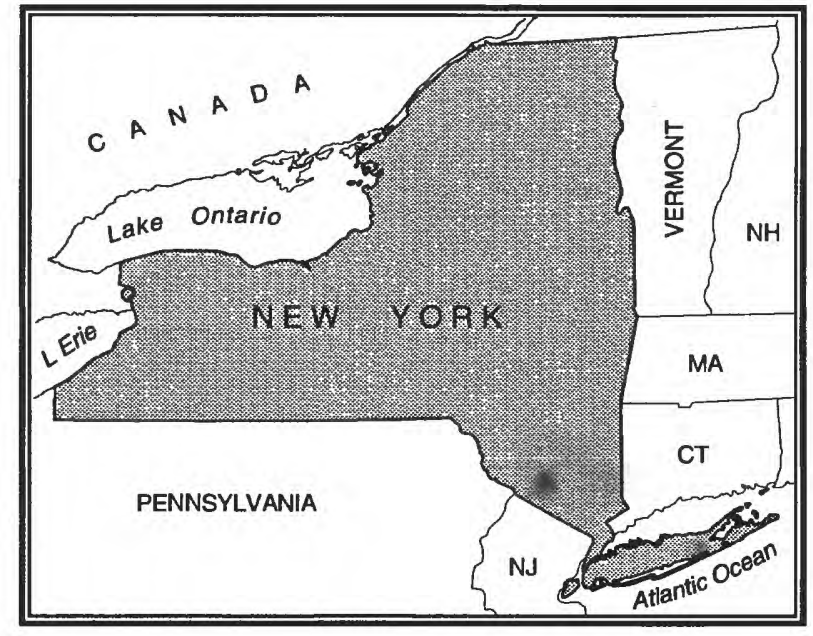

Progress and significant results: The collection and analysis of peak-discharge data continued at 56 crest-stage gages throughout New York, and flows were published in the annual water data reports. Several site studies made during the year provided the magnitude and frequency of flooding for specific bridges or culverts. The New York flood-data network is evaluated annually

Plans for next year: Data collection and analysis at crest-stage gage sites will continue. Hydrologic and/or hydraulic analyses at bridge and/or culvert sites will be made upon request. Notable floods that occur during the year will be documented in appropriate publications. A statistical log-Pearson analysis of annual peak discharges at all sites in New York with sufficient length of record is planned. Development of a regional skew map of New York is also being considered. 


\section{Transport of Polychlorinated \\ Biphenyl (PCB) Residue in the UpPer Hudson River Basin (NY 77-046)}

Period of project: Continuous since February 1977

Project leader: Jay F. Weigel

Field location: Hudson River from Fort Edward to Waterford

Cooperating agency: New York State Department of Environmental Conservation

Problem: The industrial discharge of PCBs (polychlorinated biphenyls) into the upper Hudson River has degraded the water quality. The effectiveness of proposed sediment-dredging operations in the upper Hudson remains unknown until it is determined whether such operation will cause significant quantities of PCB-contaminated sediment to be transported downstream.

Objective: To estimate the amount of PCB's contributed from the upper Hudson River to the estuary and determine whether PCB-contaminated sediments have been transported into the

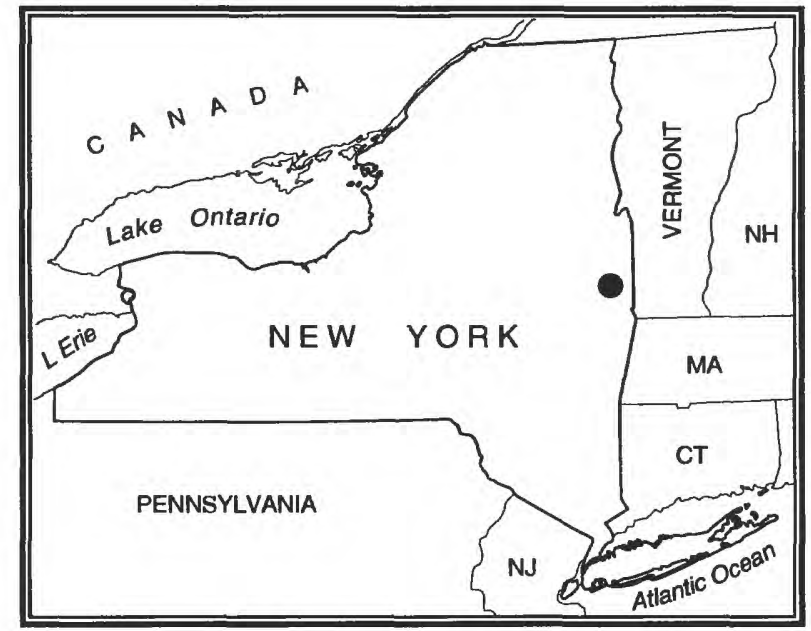

estuary. This study will provide a data base from which the effects of dredging in the upper Hudson (if carried out) can be evaluated.

Approach: Annual PCB and sediment loads for the Hudson River will be calculated from dailyflow and sediment data.

Progress and significant results: Annual suspended-sediment loads and PCB loads through water year 1993 were calculated and compared with those of preceding years. Results of samples collected through 1993 were published in the annual data report.

Plans for next year: To continue sampling the Hudson River to determine PCB levels, and to update reporting on $\mathrm{PCB}$ concentration and transport. 


\section{Hydrogeologic Assessment of \\ Selected Aquifers \\ (NY 82-114)}

Period of project: Continuous since October 1981

Project leader: Richard J. Reynolds

Field location: Glacial valleys in upstate New York

Cooperating agency: New York State Department of Environmental Conservation

Problem: Most principal aquifers in upstate

New York are isolated unconfined glacial or alluvial deposits in valleys cut into crystalline or shale bedrock. Development has rendered these aquifers susceptible to contamination. Contamination, whether from agricultural, industrial, or nonpoint sources, jeopardizes the only economical source of water for homes, communities, and small industries in many places. Decisions by State or local agencies to resolve or prevent such problems would be facilitated by an appraisal of selected aquifers with a potential for contamination.

Objectives: (1) To select aquifers that have known or potential ground-water contamination problems. (2) To compile geohydrologic maps of the aquifer systems. (3) To select a groundwater-quality monitoring system for major water-supply users. (4) To sample and analyze ground water for baseline quality.

Approach: Aquifer selection will be flexible, depending on the needs of the cooperating agency. Aquifers will be mapped generally at the 1:24,000 scale from published geologic, soils, and land-use maps or minor field mapping. Aquifer characteristics will be interpreted and depicted on aquifer-thickness, water-level, and water-quality maps and geologic sections.

Progress and significant results: A 40-well observation network was established in the

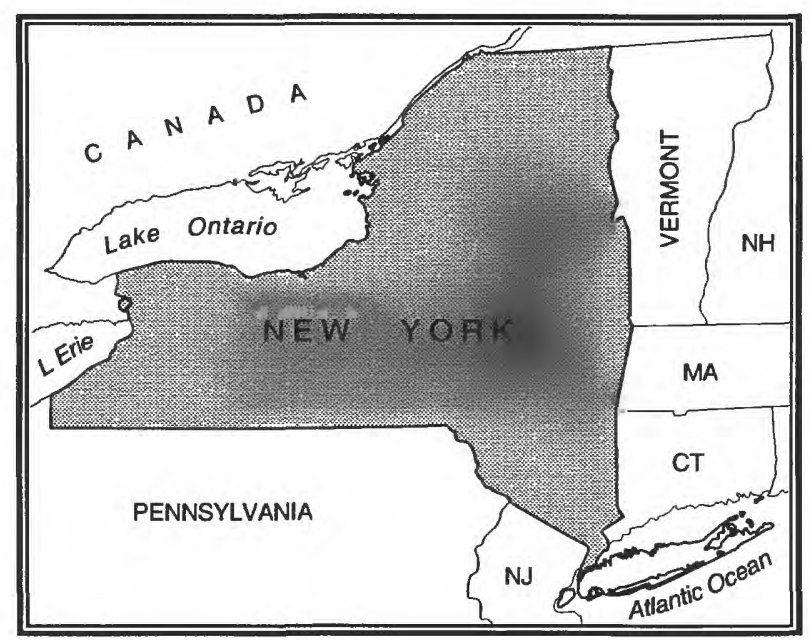

Clifton Park area to monitor water levels in segments of the confined Colonie Channel aquifer and the surficial-sand aquifer. Twenty six observation wells are screened in confined or unconfined segments of the Colonie Channel aquifer, 14 wells are screened in the surficialsand aquifer. Synoptic water-level measurements have been made quarterly since October 1992. Thirteen test holes were drilled in the Clifton Park area to obtain geologic information on the extent of buried ice-contact sand and gravel deposits. A bibliography of consultant reports that describe past hydrogeologic investigations in the Clifton Park area was compiled. A subproject to develop and maintain a hydrologicdata-collection network for the Clifton Park area was funded by the Clifton Park Water Authority.

Plans for next year: (1) To select wells for continuous water-level monitoring and equip them with either pressure transducers or floatactuated recorders. (2) To compile daily pumpage data for each supply well in the Clifton Park Water Authority service area. (3) To compile precipitation data. Select a subset of observation wells to measure on a weekly basis, and instruct Clifton Park Water Authority personnel in measurement methods. Continue with monthly synoptic water-level measurements in all remaining wells. Compile and review existing water-quality data for each production well. Seek to expand observation-well network by field inventory and investigation. Complete reports covering the Schodack-Kinderhook area, the Oxford-Brisben area, and the Port Jervis area. 


\section{Long-Term Monitoring of Streams in the Catskill Mountains (NY 85-152)}

Period of project: Continuous since October 1984

Project leader: Carolyn E. Leamond

Field location: Catskill Mountains

Cooperating agency: U. S. Environmental Protection Agency

Problem: Reconnaissance data suggest that acid precipitation can affect stream chemistry in the Catskill Mountains. Assessment of the processes that cause stream acidification and the effect of acid deposition on fish and invertebrates requires data on both short-term and long-term trends in stream chemistry.

Objective: (1) To asses the relations among soil chemistry, stream chemistry, and discharge at four streams of differing base-flow $\mathrm{pH}$. (2) To calculate a mass balance for input and output of key constituents throughout the respective watershed. (3) To compare the effect of precipitation acidity of selected storms on the chemistry of these streams. (4) To assess the effect of episodic acidification on fish and invertebrate populations. (5) To assess the long-term changes in stream chemistry at seven Catskill streams.

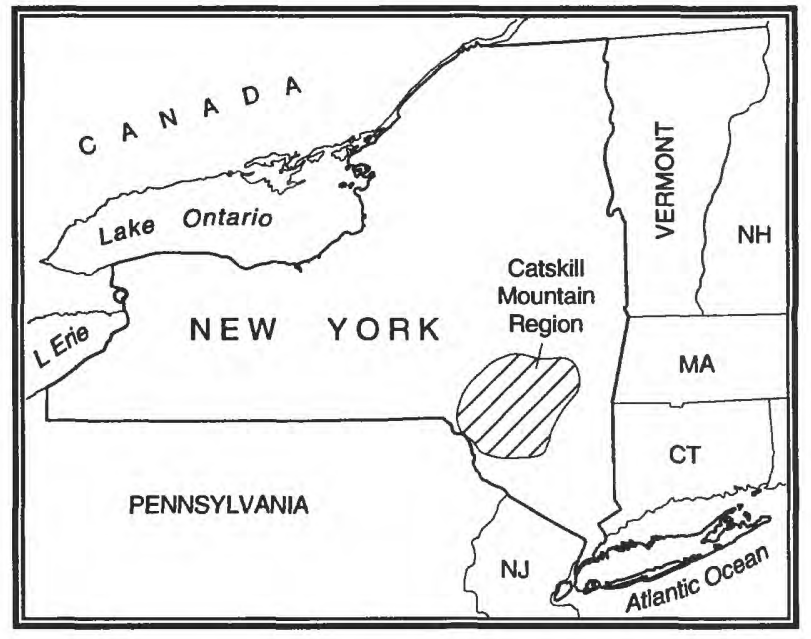

Approach: To conduct (a) hourly sampling of stream and rain during 10 storms at the four streams, (b) weekly sampling during nonstorm periods, (c) monthly sampling at seven streams peripheral to the Biscuit Brook watershed with simultaneous discharge measurements, and (d) monitoring of biologic response by population estimates, bioassay experiments, and radio telemetry studies.

\section{Progress and significant results:}

Long-term monitoring continued. Results indicate that nitrate concentrations in streams increased, and sulfate concentrations decreased, during the 1980's. Relations between constituents and flows were developed for all streams in the network. Storm data show that nitrate concentrations increased and sulfate concentrations decreased with increasing flow, except during midsummer.

Plans for next year: Continue long-term monitoring. 


\section{Evaluation of Scour at BRIDGES IN NEW YORK (NY 88-178)}

Period of project: July 1988 through September 1993

\section{Project leader: Gerard K. Butch}

Field location: Statewide, excluding Long Island and New York City

Cooperating agency: New York State Department of Transportation

Problem: No reliable technique is available to estimate scour at bridges in New York. Uncertainty as to which scour-prediction equations to use for a particular set of circumstances has prompted an effort to develop data bases that reflect full-scale, prototype field conditions. The types of channels and bridges that are vulnerable to scour, and reliable data-collection methods, need to be identified.

Objective: (1) To collect scour data to evaluate and perhaps improve current scour-prediction equations. (2) To categorize the types of channels and bridge designs vulnerable to scour. (3) To assess alternative methods of data collection.

Approach: Scour data are being collected at 77 bridges in New York. Bridges near USGS stations on streams with erodible bed material were selected in six physiographic provinces. High-flow data are being collected at 31 bridges, and annual data at the remaining 46 bridges. The conventional method of data collection with a sounding weight is being compared with sonar and other geophysical techniques for accuracy, safety, and ease of operation. Streambed cross sections measured at the beginning of the study are to be compared with bridge plans, previous measurements, and data collected during the remaining years of the project to determine the extent of scour at the selected sites. Results of scour-prediction equations will be compared with measured scour. Regression analyses and (or) other curve-fitting techniques will be used to

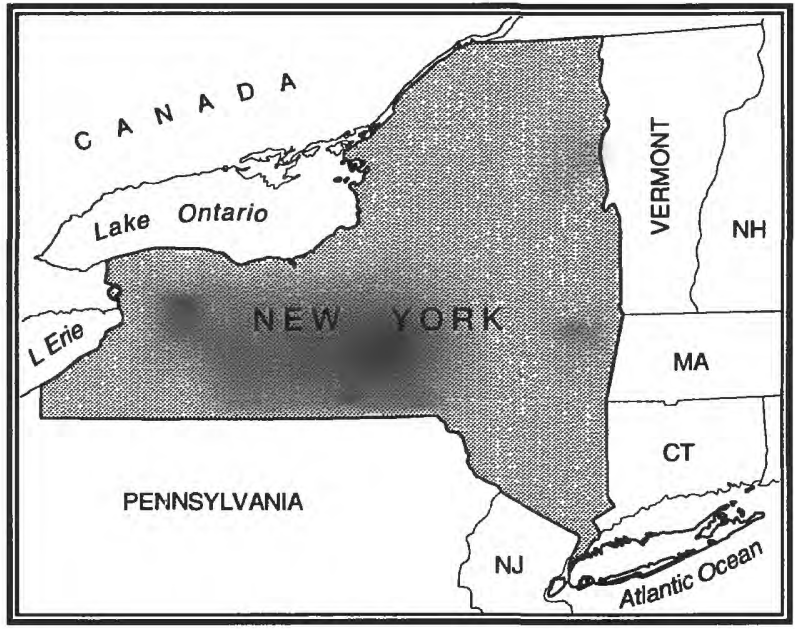

improve scour-prediction equations. The types of channels and bridges vulnerable to scour will be categorized.

Progress and significant results: Clear-water scour is common at most sites; local scour holes that formed during previous high flows did not refill. Streamflow measurements and a stepbackwater model are being used to define hydraulic properties associated with floods. Local scour increased with water depth, stream velocity, and Reynolds number, but did not correlate with bed-material size, Froude number, pier geometry, friction slope, or several other hydraulic and basin characteristics. A hydrographbased factor that incorporates the duration and magnitude of high flows and the shape of the hydrograph was developed and combined with a momentum-based factor that represents flow velocity, water depth, and bed-material size.

Geophysical techniques were applied to gravel and cobble streambeds, but did not reveal any backfilled scour holes. A fathometer provided quick and accurate depth measurements. The mobile method, which uses a four-wheel base and crane, was cumbersome. Four scour monitors are being evaluated for Federal Highways and Waterways Administration project 97, "Scour Monitoring and Instrumentation." The instruments require further evaluation because the 1955 peak flows were less than 50 percent of the mean-annual peak discharges at the study sites.

Plans for next year: To complete evaluation of scour monitors, analyze scour-hole widths, and prepare final report. 


\section{Water-Resources Data-Collection AND Monitoring Network IN THE Croton River Watershed, New York (NY 90-191)}

Period of project: July 1990 to September 1993

Project leader: Stephen W. Wolcott

Field location: Croton River Watershed (Dutchess, Putnam, and Westchester Counties)

Cooperating agency: City of New York, Department of Environmental Protection

Problem: Expanding urbanization in the Croton River watershed has led to the deterioration of water quality in the Croton Reservoir system. The water does not require filtration at present, but if current trends in urbanization and subsequent deterioration in water quality continue, filtration and other expensive types of treatment will be inevitable. Data on water use, streamflow, ground-water levels, and water quality are needed by water-resource managers to evaluate the quality and quantity of water resources in the watershed.

Objective: To summarize current and historical water-resources data and to establish a monitoring network that can be used to evaluate changes in water quality and quantity that result from urbanization within the Croton River watershed.

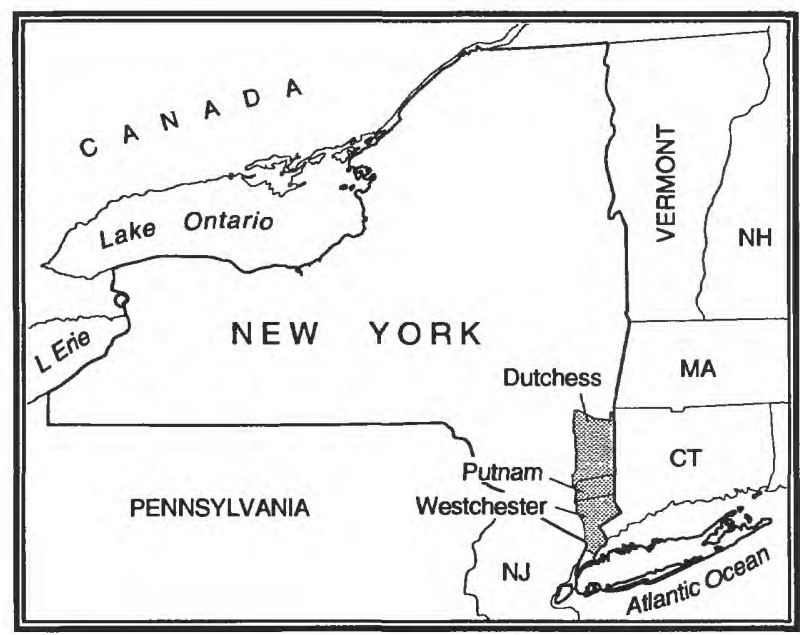

Approach: Historical water-resources data will be compiled on low flow and miscellaneous streamflow, well yields, ground-water levels, water quality, water use, and precipitation. These data will be converted into Geographic Information System (GIS) coverages, and where possible used to determine optimum locations for new stream gages, observation wells, and waterquality-measurement sites.

Progress and significant results: Many GIS data coverages were assembled and transmitted to the cooperator. Seven reservoir outflow gages were installed, and reconnaissance and planning for nine headwater gaging sites was begun.

Plans for next year: To complete GIS report and install nine new gages. 


\section{Ground-Water Resources of the Batavia Kill at Windham, Greene CoUnTY (NY 90-192)}

Period of project: May 1990 through September 1993

\section{Project leader: Paul M. Heisig}

Field location: Batavia Kill valley, Towns of Windham and Ashland

Cooperating agency: New York City Department of Environmental Protection

Problem: Development in the Town of Windham, in the drainage basin of the Batavia Kill, has raised concern about the adequacy of ground-water resources for local supply as well as the potential effect of development on the quantity and quality of surface water reaching the New York City reservoir system. In 1981, a ski center at Windham was opened to the public, and the subsequent demand for vacation homes and multi-unit dwellings has spurred development in the area. The general lack of information on water resources in the area has caused concern over the potential effect of additional development.

Objective: (1) To assess the water resources of the Batavia Kill basin near Windham by determining stratified-drift-aquifer geometry, groundwater flow directions, and hydraulic properties, and ground-water and surface-water quality. (2) To document the effects of seasonal pumping and sewage disposal on ground-water levels and water quality.

Approach: The hydrogeology of the stratifieddrift and bedrock aquifer will be determined from existing hydrogeologic well-log data, a field inventory of domestic and production wells and water-level measurements, surface- and borehole-geophysical surveys, and through drilling of test holes and installation of observation wells. Water quality will be assessed through chemical

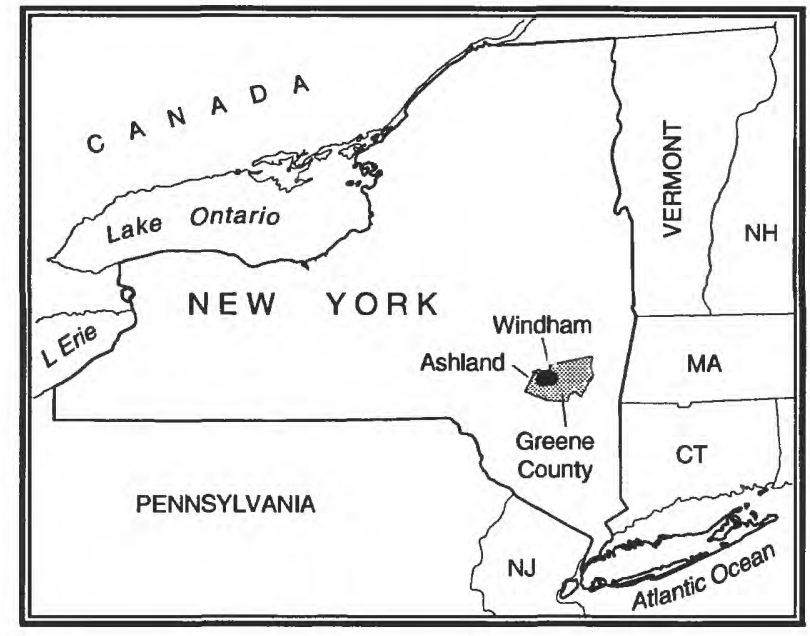

analysis of ground-water and surface-water samples. Flow in the Batavia Kill will be monitored continuously, and discharge measurements will be made in the Batavia Kill and its tributaries during low-flow periods.

Progress and significant results: Hydrochemical data from ground-water samples collected in and around the Batavia Kill valley suggest a chemical evolution along flowpaths in the most active parts of the glacial and bedrock aquifers, which results in specific major-ion water types. Deeper, less active ground-water appears to be derived form oil-field and gas-field brines and are not potable. Mixing of the various water types occurs within and among wells that intersect fractures at different depths. All water types are found within the immediate vicinity of the Batavia Kill valley.

Hydrochemical data indicate that only shallow ground water discharges to the Batavia Kill and its tributaries. The effects of human activities are most evident in low-flow samples in the study area; no constituents exceed existing water-quality regulations, however.

Flow observations and measurements indicate seepage losses from several large tributaries as they enter the Batavia Kill valley. Estimates of 7-day, 10-year and 30-day, 10-year flow at the Batavia Kill gage were completed. The effect of water withdrawals from an infiltration gallery (for snowmaking at the ski area) for both surface and ground water was documented.

Plans for next year: To complete fieldwork, interpret data, and complete the final report. 


\section{National Water-Quality Assessment (NAWQA) OF THE HUDSON RIVER BASIN (NY 91-199)}

Period of project: Continuous since January 1991

\section{Project leader: Patrick J. Phillips}

Field location: 13,400-square-mile Hudson River Basin in New York, Vermont, Massachusetts, Connecticut, and New Jersey

\section{Cooperating agency: Federally funded}

Problem: Information on water-quality conditions and factors that affect those conditions are lacking locally and nationally. A comprehensive program that combines the benefits of basinscale studies with a national assessment of water quality can help to provide the types of information needed by water-resource managers, researchers, and policy makers.

Objective: (1) To provide a nationally consistent description of current chemical, physical, and biological conditions of a large part of the Nation's water resources. (2) To define the longterm trends in these water-quality conditions. (3) To identify the major natural and human factors that affect these conditions and trends.

Approach: The Hudson River Basin National Water Quality Assessment study includes an evaluation of existing data as well as design and implementation of an intensive sampling program. Sampling sites were selected on the basis of land use and other subbasin characteristics. Many of the sites were selected to avoid point sources of pollution, because an integral part of the study is to identify the effects of nonpoint pollution.

The 3-year intensive sampling phase of the program ends in 1995. After 1995, efforts will focus on interpreting data collected during the sampling phase and producing reports. The program will enter a 6-year less-intensive sampling phase in 1996.

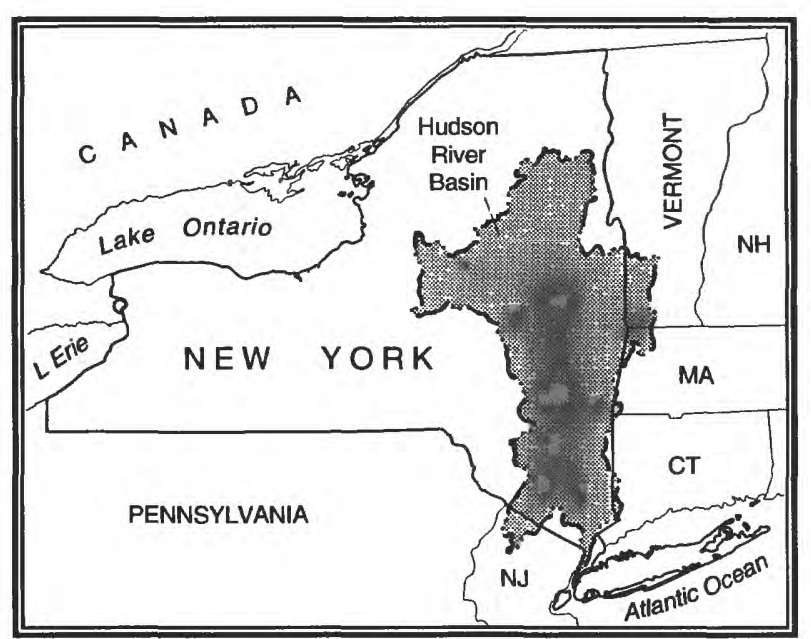

A liaison committee, consisting of representatives from other Federal agencies, State agencies, private industry, local planning commissions, environmental consulting firms, universities, and other agencies, helps evaluate the design and results of the project. The committee meets annually and is kept informed through newsletters, reports, and other mailings.

Progress and significant results: A report that evaluates existing data, and describes nutrients, pesticides, and suspended sediment in surface water and ground water is near completion. It concludes that nutrients are derived mainly from nonpoint agricultural sources.

Historic and recently collected data indicate that, during non winter and low-flow conditions, chloride can be a good indicator of point and nonpoint sewage inflows into streams. Chloride concentrations are generally highest in streams dominated by urban land use.

Preliminary fish-community data indicate that the water quality of several small urban streams might be degraded. Fish communities at the urban sites included in this study were composed completely of pollution-tolerant species. Urban sites showed low species-richness.

Plans for next year: The primary focus will be on data interpretation and the production of reports. Sampling will continue at selected sites to help identify long-term trends. 
Stream-Water Quality as a Function of Watershed Scale IN THE NEVERSINK RIVER IN THE Catskill Mountains (NY 91-200)

Period of project: October 1990 through September 1995

Project leader: Gregory B. Lawrence

Field location: Catskill Mountains

Cooperating agency: New York City Department of Environmental Protection

Problem: Maintaining the water quality of Catskill reservoirs that supply drinking water to New York City requires a detailed knowledge of watershed processes that control the chemical quality of streams and rivers that flow into the reservoirs.

Objective: (1) To define water-quality relations between the Neversink River and upstream drainages by assessing the chemical changes along streams throughout the basin. (2) To develop quantitative relations among stream chemistry, discharge, and watershed characteristics. (3) To develop methods to integrate waterquality data from watersheds at differing scales.

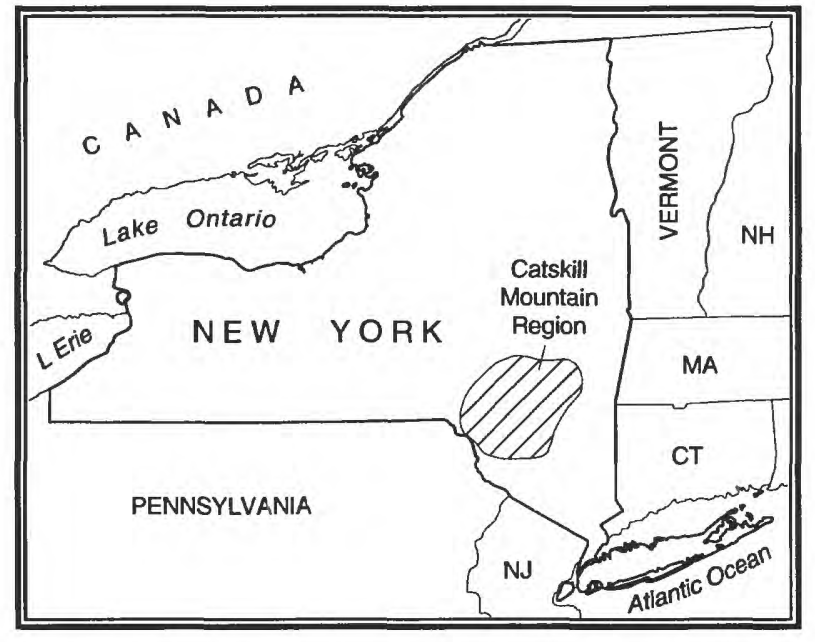

Approach: Conduct a detailed spatial analysis of surface-water quality throughout the basin. Relate topographic characteristics and other watershed factors to spatial variations in stream chemistry. Evaluate temporal variability of streamflow and chemistry at differing watershed scales.

Progress and significant results: Data collection phase is nearly complete, and data interpretation is underway. The workplan is published. GIS coverages are nearly complete, and a manuscript on dissolved nitrate transport is in preparation.

Plans for next year: To complete field sampling, continue deposition monitoring, complete transport nitrate report. 
Biogeochemical Processes that Control Nitrogen Cycling and Associated Hydrogen and Aluminum

LEACHING IN AN UNDEVELOPED

Headwater Basin

(NY 91-204)

Period of project: July 1991 through September 1997

Project leader: Peter S. Murdoch

Field location: Neversink River basin

Cooperating agency: New York City Department of Environmental Protection

Problem: Nitric acid is the primary mineral acid that causes a decrease in $\mathrm{pH}$ and increases in inorganic aluminum concentrations in streams during storms and snowmelt in the Catskill Mountains. Processes that control nitrogen movement in forested catchments are poorly understood. Information on nitrogen processes and movement in forest soils is needed to define the flowpaths of water and the transport of aluminum in watersheds.

Objective: To (a) identify the processes that control nitrogen storage and movement in forested watersheds, (b) describe relations among processes that control concentration and movement of nitrogen and dissolved organic carbon compounds, and (c) identify the effect of these processes on aluminum mobility in forest soils.

Approach: To monitor soil water, ground water, soil gas, and atmospheric deposition in

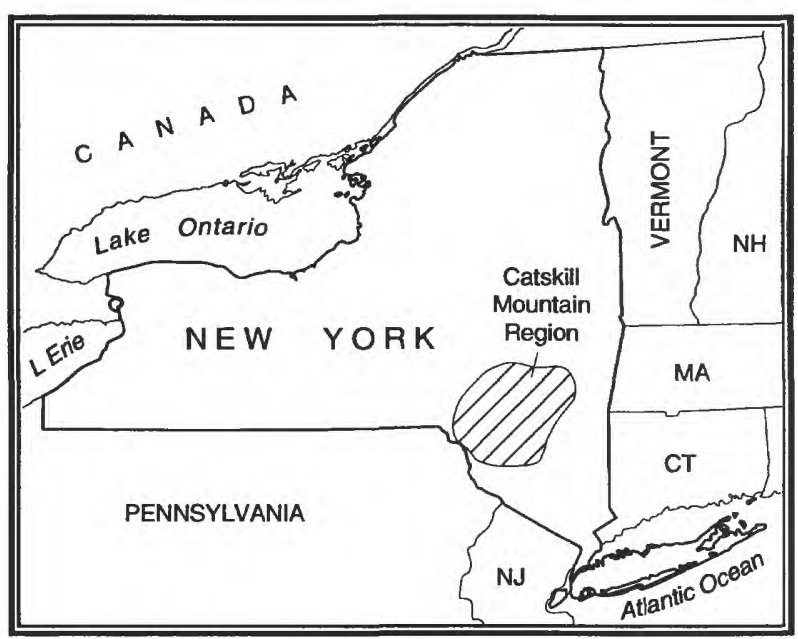

three similar watersheds for 2.5 years; one watershed will be cut 40 percent (common logging practice), one will remain pristine. Monitoring will then continue for 4 years. Automated samplers will be used to collect soil and stream water during selected storms. Soil bags with homogenized B-horizon soil will be buried below the O-horizon throughout each watershed and collected every 6 months and analyzed to determine rates of nitrification and weathering.

Progress and significant results: Data on watersheds before cutting have been collected for 3 years and indicate that ground-water seeps strongly affect surface-water quality in the lower parts of each watershed, and vegetation strongly affects nitrogen movement in the forested hillslope.

Plans for next year: To begin logging of the clearcut and 40-percent-cut watersheds and continued intensive monitoring through the cutting period. 


\section{PCB and Trace Metal Loads to Lake Champlain from Tributary STREAMs (NY 92-206)}

Period of project: April 1992 through August 1996

Project leader: L. Grady Moore

Field location: Lake Champlain Basin in Vermont, New York, and Canada

\section{Cooperating agency: Federally funded}

Problem: The water quality of Lake Champlain is being investigated under provisions of the Lake Champlain Special Designation Act. The Technical Advisory Committee (TAC) has been established to plan and implement studies. The Lake Champlain Management Conference (LCMC) and the studies being conducted in the basin need basic GIS coverages to support their analysis.

Objective: To provide technical management expertise to help the Conference meet its goals. To provide reliable GIS coverages at a 1:24,000 scale and make them available to all LCMC project activities. The primary coverages are (a) drainage-basin boundaries at the 11-digit basic code level, (b) streams within the basin, (c) transportation network, and topographic contours.

Approach: The New York and Vermont/New

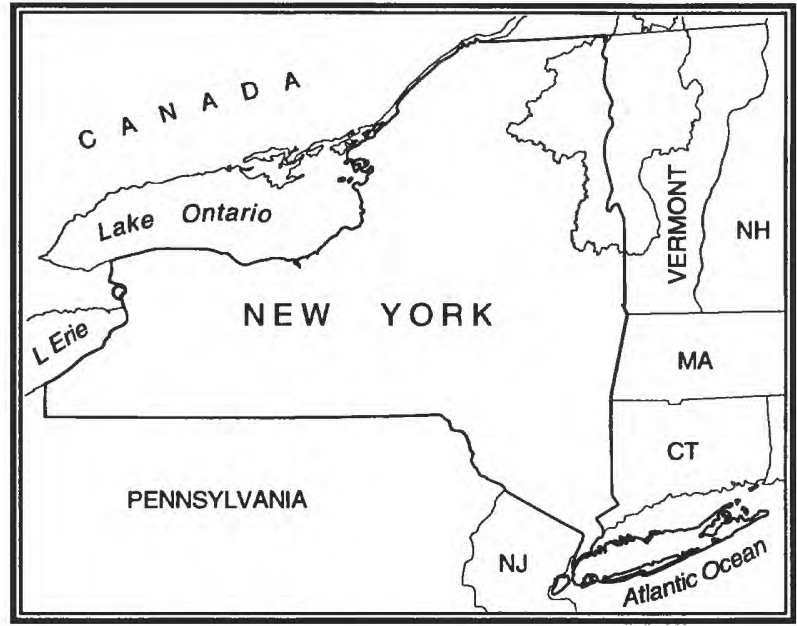

Hampshire USGS offices will work with the New York and Vermont Soil Conservation Service offices to certify drainage boundaries. The USGS will convert the boundary lines on the topographic quadrangle sheets to digital coverages and provide quality assurance for the data. The New York District will scan the streams from 1:24,000 mylar separates and develop digital coverages. If possible, they will do the same with the contours within the basin.

Progress and significant results: Drainagebasin-boundary coverages were completed and transferred to the Lake Champlain Management Clearinghouse at the Vermont Center for Geographic Information. Streams in the New York part of the basin were digitized. Transportation in the New York part of the basin was digitized to update and extend information from the Adirondack Park Authority.

Plans for next year: To complete stream coverages in the Vermont part of the basin and begin transportation coverages. 


\section{Aluminum and Calcium Chemistry in Red Spruce Forests: Relations among Acid Deposition, Root Vitality, and Stand Dynamics (NY 92-208)}

Period of Project: October 1991 through September 1996

Project Leader: Gregory B. Lawrence

Field Location: New York, Vermont, New Hampshire and Maine

Cooperating Agency: U.S. Forest Service

Problem: Dieback of red spruce trees in the Northeast has been linked to possible changes in soil chemistry caused by acidic deposition, but a scientific consensus has not been reached on whether acidic deposition has caused changes in soil chemistry, nor whether the proposed changes in soil chemistry could be causing the dieback. Relations between acidic deposition, red spruce health, and soil-calcium cycling may also be affecting surface-water quality, but these linkages have not been investigated.

Objectives: (1) To conduct an evaluation of soil and soil-solution $\mathrm{Al}$ chemistry in conjunction with an assessment of red spruce health. (2) To identify the processes through which acidic deposition affects soil chemistry and red spruce growth.

Approach: The study involves sampling of 13 sites in northern New York and New England.

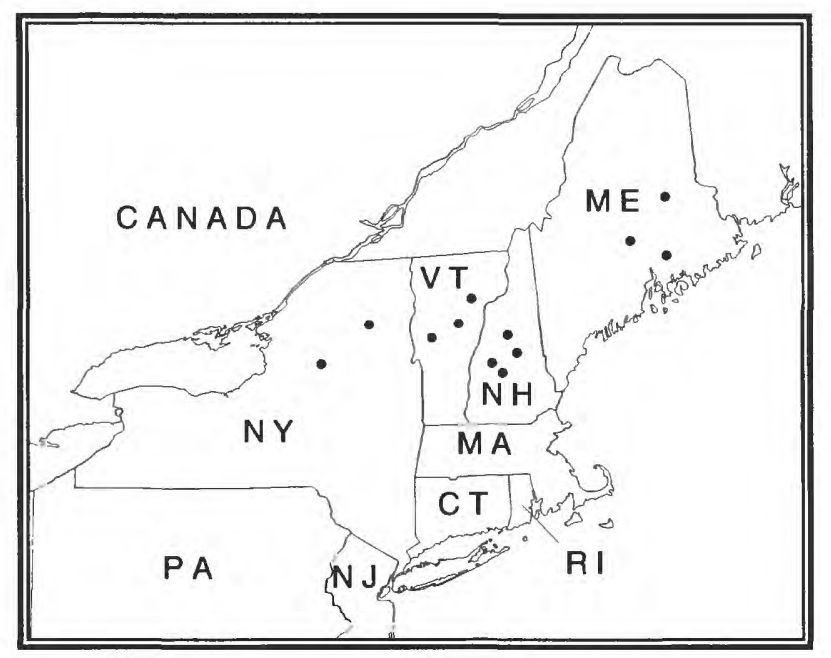

Soil, soil solution, roots, tree cores and foliage have been collected two to four times at each site. At three of the sites, combinations of calcium and nitrogen fertilizer have been added for 4 years to evaluate how trees will respond to increased availability of these nutrients.

Progress and Significant Results: (1) A new technique was developed to evaluate soil-solution chemistry during the summer, when soils tend to be dry. (2) A regional decline in calcium concentrations in the rooting zone was discovered, and an increase in reactive $\mathrm{Al}$ concentrations in the rooting zone was discovered. The $\mathrm{A} 1$ increase was linked to the decrease in calcium concentrations and is due largely, to acidic deposition.

Plans for next year: Soil will be evaluated with tree and root measurements to determine whether acidic deposition is related to a decline in tree health. 


\section{Variable Source-Area Control of Episodic Stream Chemistry (NY92-209)}

Period of Project: October 1991 through May 1996

Project Leader: Gregory B. Lawrence

Field Location: Grafton County, New Hampshire

\section{Cooperating Agency: U.S. Forest Service}

Problem: Episodic or short-term acidification is one of the most significant effects that acidic deposition has on surface-water quality. Investigations of episodic stream acidification have focused primarily on soil-water flowpaths without considering the effects of local landscape variations. Even within small watersheds, local variations in particular areas contributing surface runoff during a storm can affect in stream water chemistry. Information on how areal variability within watersheds affects the timing and degree of acidification is important for assessing the effects of episodic acidification.

Objectives: To evaluate the effects of variable hydrologic source areas on stream chemistry and incorporate this information into a simulation model that could be applied to other watersheds.

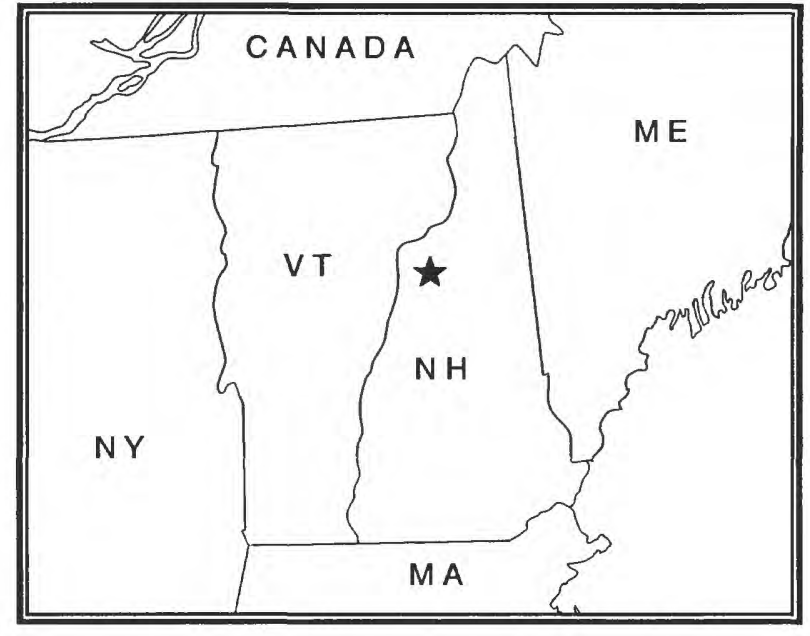

Approach: The project involves a combined field measurement and modeling approach implemented in two phases. In Phase 1, information will be obtained through field investigations of variable source-area controls of stream chemistry. In Phase (2) this information will be incorporated into hydrologic model (TOPMODEL) to simulate how variable source areas control episodic stream chemistry.

Progress and significant results: Completion of Phase 1 indicated that areal variation in soils and vegetation was an important control of episodic changes in stream chemistry in the study watershed. During high-flow conditions, surface flow was generated at the uppermost reaches of the watershed, where soils were most acidic, and caused a $\mathrm{pH}$ depression in stream water leaving the watershed.

Plans for next year: To complete the final report. 


\section{Estimation of Contributing Areas to Public Water-Supply Wells and Flow Paths from Contaminant Sources in the GLacial-Drift Aquifer at Cortland (NY 89-184)}

Period of project: June 1989 through September 1993

Project leader: Todd S. Miller

Field location: Cortland County

Cooperating agency: Cortland County Health

Department

Problem: Increasing development above the Cortland aquifer and several chemical spills, including trichloroethylene (TCE) from an industry, gasoline from leaking storage tanks from at least two service stations, and leachate from inactive hazardous-waste sites, have degraded the water quality in parts of the aquifer. The movement and fate of the contaminants need to be tracked to avoid adverse effects on human health.

Objective: To (a) expand and refine knowledge of the hydrogeologic setting and ground-water flow system of the Otter Creek-Dry Creek aquifer, (b) estimate the zones of contribution and traveltimes to public water-supply wells. Determine the extent of the TCE plume, (c) determine the general water quality of the aquifer, with emphasis on organic chemicals, and (d) estimate ground-water flow paths and traveltimes from potential and known sources of contamination to the discharge areas.

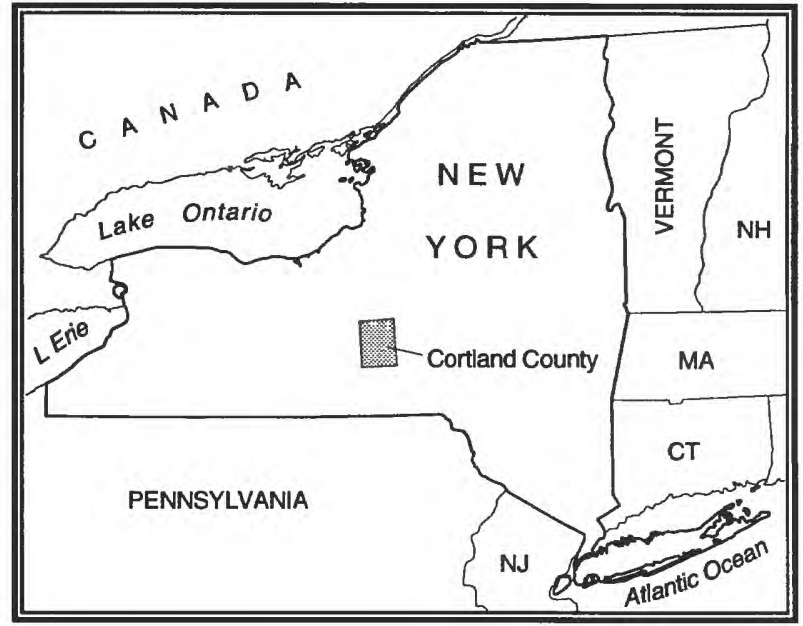

Approach: A modular quasi-three-dimensional model will be constructed and coupled with a particle-tracking routine to simulate flow paths and traveltimes. Surface geophysical surveys, such as seismic refraction and marine reflection will be used; also 25 test holes will be drilled, to determine stratigraphy, aquifer geometry, and water levels. Water samples will be collected from 50 wells and analyzed for purgeable organic compounds and several inorganic constituents.

Progress and significant results: Most fieldwork, including drilling of 25 test wells, two seismic surveys, and sampling of 50 wells twice, was completed. Geologic sections depicting stratigraphy were drawn and the quasi-3dimensional model was constructed. Water levels in about 100 wells and streamflow at about 25 sites were measured three times-once each during average-high, average, and averagelow conditions. The TCE plume was mapped.

Plans for next year: To write final report. 


\section{Probabilistic Assessment of Atrazine Contamination in Ground WaTer (NY 90-186)}

Period of project: October 1989 to September 1993

Project leader: David A. Eckhardt

Field location: Kansas River Valley Experiment Field, Topeka, Kansas

Cooperating agency: Federal (USGS Toxic Substance Hydrology Program)

Problem: Results of multidisciplinary research into processes and factors that affect the transport and chemical fate of the herbicide atrazine in the unsaturated zone, and the susceptibility of ground water to contamination by atrazine, need to be evaluated through probabilistic solutetransport models.

Objective: To (a) assess current knowledge of processes and factors that affect atrazine mobility in the hydrologic environment and integrate findings into appropriate models; (b) identify and statistically characterize key variables; and (c) develop probabilistic representations of atrazine transport to ground water through stochastic simulations with transport models.

Approach: Selected unsaturated-zone transport models will be evaluated and modified to develop a working set of analytical and numerical models for parallel applications. A sensitivity analysis of selected model variables will be conducted, data needs will be identified, models

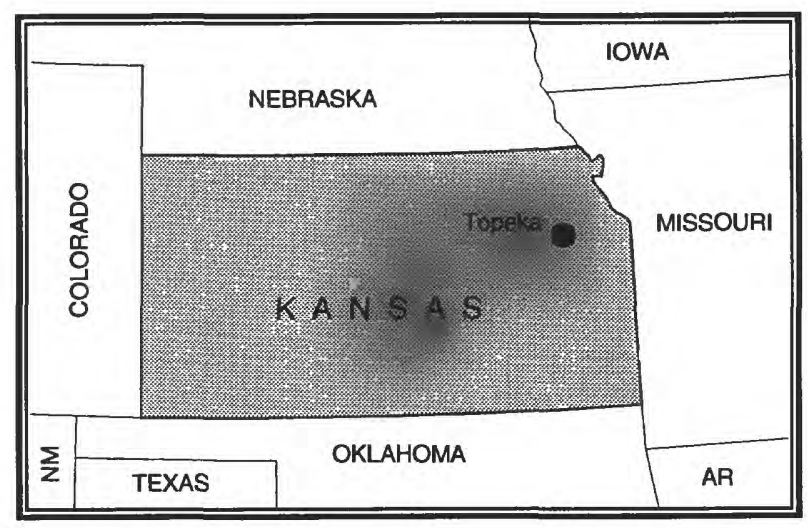

will be evaluated through field and laboratory data, and predictions of the potential for atrazine contamination of ground water will be verified through model simulations and appropriate field data.

Progress and significant results: Physical and hydraulic properties of soils at the agricultural field site were spatially delineated, and models that describe soil-water movement were developed and unsaturated-zone flow models that describe soil-water movement at the field site also were developed. A bromide tracer and two herbicides (atrazine and alachlor) were applied to the 0.75 -hectare plot in 1991, and core samples of soil were collected for chemical analysis of spatial and temporal solute distributions.

Plans for next year: (1) Continue soil-water modeling and include spatial variability of physical properties and boundary conditions, and complete solute-transport-model analysis with 1991 field data (soil-core analysis). (2) Conduct laboratory studies of herbicide sorption on soils from the field site to provide information needed for transport models. 


\section{Effects of Stormwater Detention IN WETLANDS OF THE LOWER Irondequoit Creek Basin Near ROCHESTER, New YoRK (NY 90-190)}

Period of project: October 1990 through September 1996

Project leader: William F. Coon

Field location: Irondequoit Creek Wetlands, Rochester, N.Y., Monroe County

Cooperating agency: Monroe County Health Department

Problem: Irondequoit Creek, which flows through an expansive flood-plain wetland into Irondequoit Bay, has been identified as a significant source of nonpoint-source pollutants. The USGS studied the Irondequoit basin as part of the National Urban Runoff Program (NURP) in 1980-81. A recommendation arising from that study was to evaluate the possibility of using the wetland as a natural detention area for stormwater for removal of nutrients and thereby improve the quality of water entering Irondequoit Bay.

Objective: To (a) evaluate the use of the floodplain wetlands at the mouth of Irondequoit Creek as a nutrient and sediment filter, (b) determine the effects of increasing detention time and dispersal of stormwater runoff and its associated constituents on a monocultural cattail (Typha glauca) wetland after flow modification, and (c) document the present and future floral and faunal structure of the wetland, and evaluate ecosystem changes that could affect the multiple-use value of the wetland.

Approach: Baseline discharge and waterquality data will be collected upstream and downstream of the wetland area along Irondequoit Creek. The chemical quality of

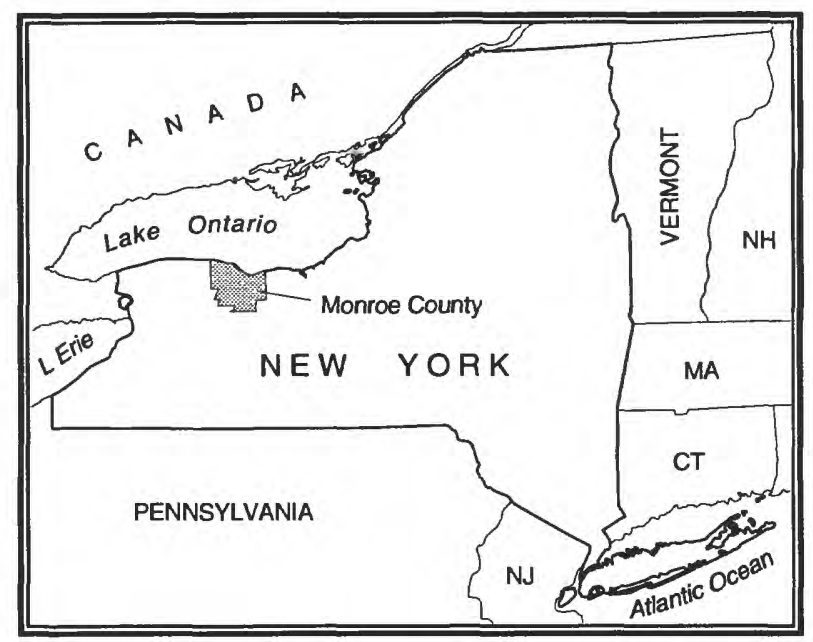

atmospheric deposition will be measured to identify its nonpoint-pollutant contribution. After implementation of flow regulation to improve flow dispersion and detention within the wetlands, discharge- and water-quality-data collection will continue so that resultant changes can be documented. Flora and fauna surveys will be conducted periodically to document ecological changes. Shallow sediment and planttissue samples taken along transects in each wetland unit will be analyzed to document changes in the accumulation of nutrients, trace metals, and organic compounds.

Progress and significant results: Streamflow and water-quality data were collected at both monitoring sites. Sediment accumulation on the sediment pads indicates that, after the initial deposition the first year, sedimentation rates attained a near-equilibrium state in the system. Water-quality loads are being computed. Project staff continued to assist the Monroe County Health Department with permit-processing activities for the proposed flow-modification structure.

Plans for next year: To (a) continue measurement of streamflow and water quality at gaging stations, (b) finish constituent load computations, (c) collect sediment samples for analysis, and (d) assist cooperator in permit-processing activities and installation of flow-control structure. 


\section{Hydrogeology of The Tully Valley MudBoILs (NY 92-205)}

Period of project: October 1991 through September 1995

\section{Project leader: William M. Kappel}

\section{Field location: Onondaga County}

Cooperating agency: Onondaga Lake Management Conference

Problem: Mudboils, or mud volcanoes, have been documented for nearly 100 years in the Tully Valley of central New York. Mudboils are volcanolike cones formed by the discharge of turbid (silty) ground water and fine sand. The cone of fine sand can range from several inches to several feet high and from several feet to 30 feet in diameter. Where mudboil activity is persistent, land subsidence due to removal of sediment at depth can occur.

Objective: Data on the origin of the mudboils, their persistence, and the possible extent of their migration is needed to mitigate or remediate land subsidence and the degradation of Onondaga Creek through turbidity, fine-sediment deposition, and chloride loading. Data on the stratigraphy of glacial deposits and hydraulichead distribution within them is needed to determine the source(s) of pressure gradients that cause ground water to discharge through the mudboils.

Approach: The flow discharging from the main mudboil depression area (MDA) will be calculated as the difference between inflow to the MDA and outflow leaving it. Sediment concentrations at the outflow-measurement flume will be measured through daily and storm sampling. The stratigraphy of the unconsolidated glacial deposits will be defined through a phased drilling program. A series of exploratory holes (about

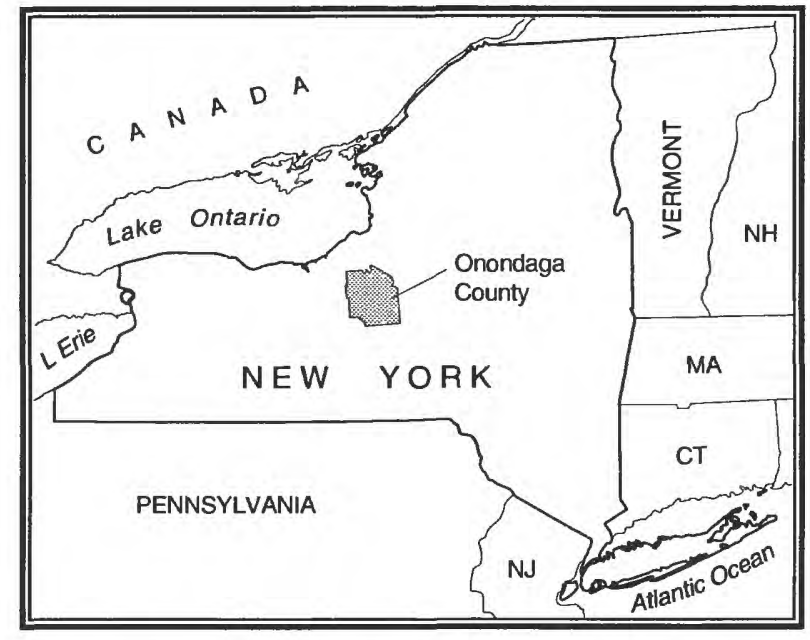

125 feet deep) will define the regional stratigraphy of unconsolidated deposits. Monitoring wells will be installed in the more permeable zones for determination of hydraulic head profiles. Results of the first phase of drilling will guide the subsequent phases as to the location and depth of drilling, to determine grain size, plasticity, and moisture content of the materials encountered. General field determinations of water quality will be made during the drilling program.

Progress and significant results: Flow from the mudboils within the MDA varies seasonally from a high of $400+$ gallons per minute $\mathrm{gal} / \mathrm{min}$ in the spring to a low of $180 \mathrm{gal} / \mathrm{min}$. in the fall of each year. Remedial measures at the MDA have reduced sediment loading from 20-30 tons per day to as low as 0.25 tons per day. Two depressurizing wells installed by the collapsed Otisco Road bridge have reduced ground-water pressures by several feet and slowed subsidence in this area. The two sidewall valleys have tentatively been identified as the source of artesian pressure in the upper mudboil source-zone.

Plans for next year: (1) To limit data collection to the downstream (outflow) flume. (2) To prepare a report summarizing 1992-94 data collection/analysis activities. (3) To install depressurizing wells at the MDA, and monitor changes in flow and sediment discharge (if funds are available). (4) To conduct aquifer tests on the two side-valley alluvial fans to determine their hydraulic connection to the freshwater mudboil source zone. 


\section{Use of Wetland Systems to Treat LEACHATE (NY 92-207)}

Period of project: July 1992 through September 1996

Project leader: Jan M. Surface

Field location: Monroe County

Cooperating agency: Monroe County Department of Solid Waste

Problem: Infiltration of precipitation and migration of ground water through landfills produce leachate that contains toxic organic and inorganic chemicals. Nearly all landfills in humid areas produce leachate, and this leachate has long been a source of ground-water and surface-water contamination. Wetlands have been shown to successfully renovate municipal wastewater, and a preliminary study at the Tompkins County landfill indicates that wetlands also have the capacity to renovate landfill leachate.

Objective: To determine whether treated landfill leachate discharged from a constructed wetland system meets State and national pollution-discharge-elimination standards, and identify the nature of water-renovating processes within the system and their capacity to treat the leachate.

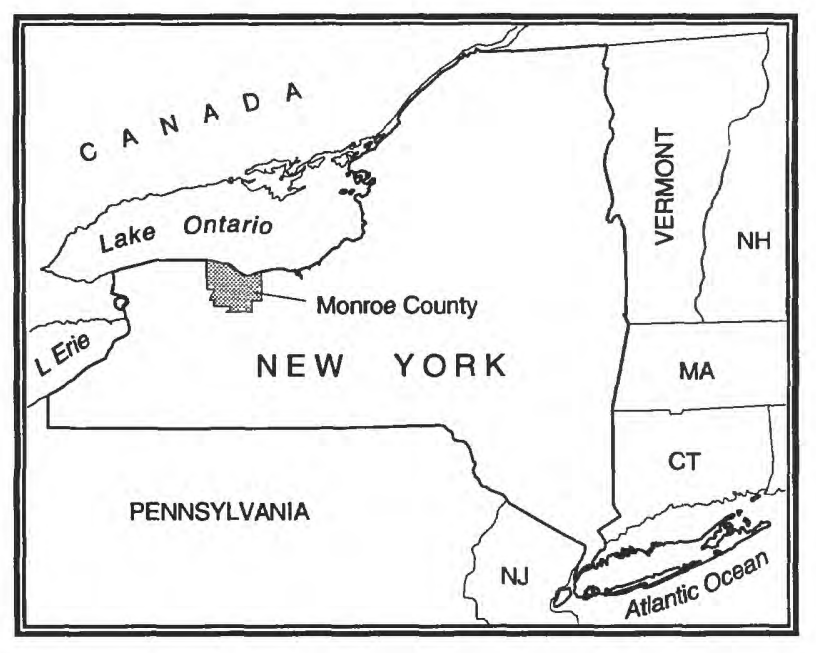

Approach: A wetland system will be constructed at the Frank E. Van Lare Sewage Treatment Facility in Monroe County. The site is representative of hydrogeologic settings of many landfills in humid regions. The system will consist of an overland-flow pretreatment area that discharges into a constructed rock-andreed wetland. Samples of influent and effluent will be collected biweekly and analyzed for selected organic and inorganic constituents.

Progress and significant results: The wetland system was constructed and planted, and the instrumentation was installed. The leachate application was postponed until April 1995 to allow for further plant growth.

Plans for next year: Leachate application and monitoring of soil, plants, and water will begin. 


\section{Northeast Atlantic Coastal Plain Ground-Water Quality Regionalization Study (NY 89-180)}

Period of project: October 1988 to September 1993

Project leader: Paul E. Stackelberg

Field location: Nassau and Suffolk Counties

Cooperating agency: Federally funded

Problem: Recent studies of nonpoint-source contamination of ground water have established significant statistical relations between shallow contamination and certain human activities and hydrogeologic factors. Additional research is needed to determine whether the effects of human activities are evident along projected flow lines in deep parts of aquifer systems.

Objective: This project is designed to statistically evaluate water-quality data from several depth intervals of the Long Island aquifer system beneath five areas of differing land uses to determine whether constituent concentrations differ significantly as a function of depth, land use, or a combination of depth and land use.

Approach: Nonparametric statistical techniques will be used to determine the probability of differences in water-quality among land-use areas and among aquifer-depth intervals within and between land-use areas.

Progress and significant results: The following results are discussed in the final report. Analyses of water samples from the shallow and intermediate zones indicate that concentrations of inorganic constituents were lowest and least variable in the undeveloped area, and generally highest and most variable in the agricultural area. Concentrations in the two sewered suburban areas generally were medium to high. Volatile organic compounds were detected only within the suburban areas.

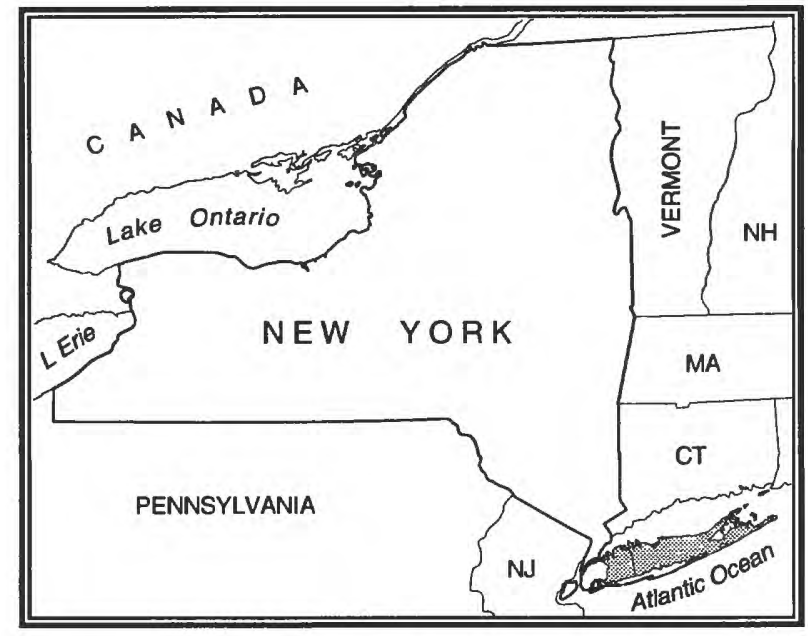

Traveltime of ground water along vertical flow paths from the water table to the midpoint of each well screen indicates that water in the deep zone is old enough to represent pristine (predevelopment) water quality. Concentrations of inorganic constituents in samples from the deep and overlying intermediate zone were more variable, and the median concentrations higher, than those from a data set representing predevelopment ground-water quality. This difference indicates downward migration of these constituents and is attributed to local pumping, which accelerates the downward flow of shallow ground water to intermediate and deep zones of the aquifer system by increasing the vertical hydraulic gradient.

Median concentrations of inorganic constituents in shallow and deep zones of the three suburban areas and detection frequencies of volatile-organic-compound detection from all depths within each suburban area indicate an improvement of ground-water quality in the long-term sewered area. Median concentrations of several inorganic constituents in the shallow zone, which represents relatively young water, were highest in the unsewered and recently sewered areas as a result of the continued loading from cesspools, septic tanks, and nonpoint sources, and the persistence of inorganic compounds introduced before sewers were constructed. The highest median concentrations in the deep zone, which represents relatively old water, were in the long-term sewered area, which has been developed the longest.

Plans for next year: Project is complete. 


\section{Modifications of RECHARGE STRUCTURES (NY 89-182)}

Period of project: October 1988 through December 1994

Project leader: Henry F. H. Ku

Field location: East Meadow Brook, Nassau County

Cooperating agency: Nassau County Department of Public Works

Problem: Urbanization has caused a decline in the water table through loss of recharge through (1) sanitary sewers, (2) increased discharge of storm runoff from paved areas to streams, and (3) increased pumpage. In turn, base flow has decreased, stream length has decreased, wetland area has diminished, and the amount of fresh ground water has decreased. The increased discharges of storm runoff to streams also has increased bacteria loading to the surrounding bays.

Objectives: (1) To evaluate the hydrologic and water-quality effects of stream-channel modification in urban streams. (2) To quantify changes in peak flow and in bacterial and chemical loads as stormflow passes through stream-modification structures. (3) To examine how changes in ground-water levels affect the relation between stream and aquifer. (4) To determine how to efficiently lengthen streams and increase recharge.

Approach: To obtain detailed drainage-basin data and establish rainfall-runoff, rainfallrecharge, and peak-discharge relations. Historical discharge records and water-quality data will be examined, and discharge will be measured

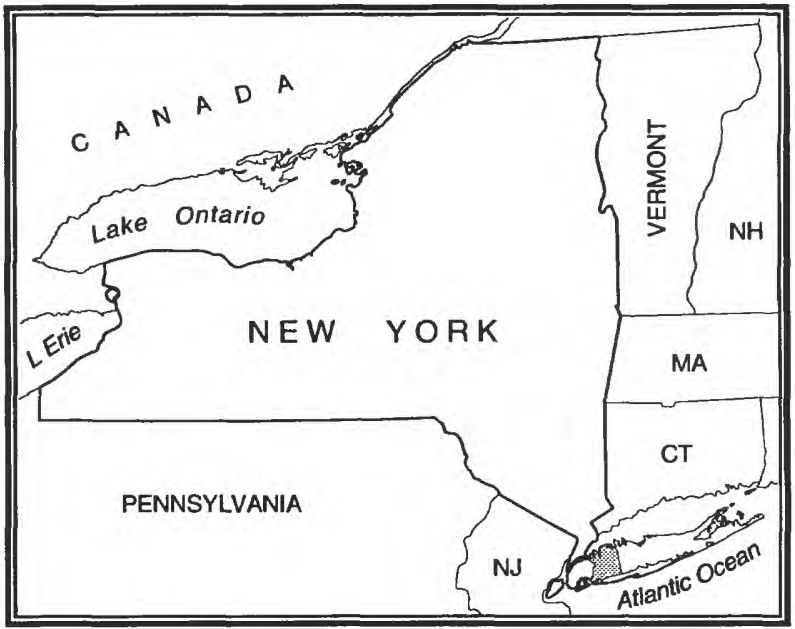

during storms and dry weather. Water-table altitudes will be monitored after installation of flow-modification structures.

Progress and significant results: Analysis of storm runoff indicates a closed system with good correlation among variables. The relation between rainfall and recharge in the study area appears to change seasonally. A relation was found between storm intensity and peak discharges. Successful dye-dilution discharge measurements were obtained for stages greater than 3.5 feet. Results of geophysical logging of the well network indicate that a clay layer underlies the northern part of the recharge structure and probably will reduce the infiltration rate. Monitoring of water-quality indicators in storm runoff indicates that the highest chemical and bacterial loading occurs during the beginning of the storm. Bacteria in stormwater detained by the recharge structure are substantially reduced over a 1-day detention period. Road-salting has caused elevated concentrations of sodium and chloride in stormwater and shallow ground water. Impoundment of storm water and shallow ground water has locally increased the ground-water level and hydraulic gradient.

Plans for next year: To complete all reports. 


\section{Iron IN THE LoNG IsLAND Ground- Water System (NY 90-196)}

Period of project: October 1989 to September 1995

Project leader: Donald A. Walter and Craig J. Brown

Field location: Suffolk County

Cooperating agency: Suffolk County Water Authority

Problem: Elevated iron concentrations in parts of the Long Island ground water system have led to the degradation and biofouling of several public-supply wells. Consequently, water suppliers must undertake costly well-redevelopment and abandonment programs. Iron-related fouling is due to the growth of iron bacteria on well screens and in the surrounding formation. Factors that may affect biofouling in publicsupply wells and require further investigation include the addition of pump-lubrication waters, well replacement, and pumping frequency. Also, the distribution and reactivity of the major ironbearing source minerals and organic carbon sources within the ground-water system play a role in local geochemical conditions and require further study.

Objectives: To (a) assess the effect of ironrelated biofouling on the Suffolk County Water Authority (SCWA) well network, (b) determine the spatial distribution of water-quality constituents that affect the biofouling process in Suffolk County, (c) identify the geochemical and hydrologic processes responsible for iron-related biofouling, and (d) assess the role and source of iron bacteria involved in the process.

Approach: Water quality and specific capacity databases will be assembled from the USGS and local databases and used to generate GIS coverages. Water-quality data from "normal" and "problem" wells will be statistically compared to identify constituents that affect the biofouling process. The spatial distribution of these con-

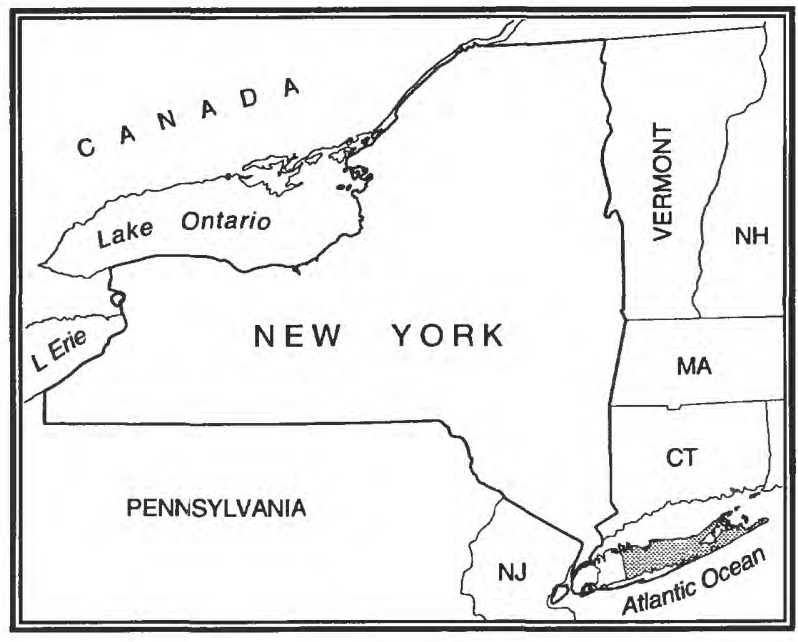

stituents in Suffolk County will be determined. Water-quality data collected during the redevelopment of "problem" wells will be used to determine saturation indices for iron and manganese minerals and to document the effects of iron bacteria on water quality. Dissolved oxygen and ferrous and ferric iron data will be collected and used to estimate redox conditions in the fouled wells. Encrusting material will also be collected and used to assess the consortia of filamentous iron bacteria in the biofilms. Core samples from test borings and circulation water will be tested for the presence of iron bacteria.

Progress and significant results: Most wells with large specific-capacity decreases were near ground-water-discharge zones, and had higher concentrations of iron-related constituents. Filamentous iron bacteria in the biofilms, including Gallionella ferruginea, were present and identified in 32 out of 42 biofouled wells and also were found in test borings. Dissolvedoxygen and ferrous- and ferric-iron data were used to estimate redox conditions in the fouled wells. Chemical and mineralogical data show that encrusting materials found in the problem wells consisted mainly of amorphous ferric hydroxide and formed largely when the wells were shut down. Two reports have been completed and are in the review process.

Plans for next year: To study the iron chemistry of ground water and aquifer material along flow paths and in the vicinity of public-supply wells, through geochemical modeling. Potential effects of well siting on iron fouling will be studied. 


\section{Geohydrology of Northern Nassau CounTY (NY 91-202)}

Period of project: October 1990 through September 1996

\section{Project leader: Frederick Stumm}

Field location: Northern Nassau County

Cooperating agency: Nassau County Department of Public Works

Problem: Increased ground-water use in northern Nassau county has predicated the need for detailed knowledge of the hydrologic and hydrogeologic framework of the area. Northern Nassau County contains many necks and peninsulas surrounded by saltwater bays and inlets. This proximity of saltwater, coupled with an ever-increasing demand for the limited supply of underlying fresh ground water, causes concern over the possibility of saltwater intrusion.

Objective: To (a) investigate and delineate the present position of a freshwater-saltwater interface, (b) determine hydraulic separations and connections between aquifers and local ground-water flow patterns, and (c) map hydrogeologic units in detail.

Approach: (1) Develop a water-level monitoring network within the study area, and measure and map water-table and potentiometric-surface altitudes to determine hydraulic gradients within and between aquifers. (2) Compile available ground-water data, water levels, chloride analyses, and geophysical logs to provide a data base from which future drilling sites can be identified. (3) Analyze water samples from selected wells for major inorganic constituents, particularly chloride, at regular intervals. (4) Compile hydrogeologic maps and cross sections from previous studies to determine future drilling sites for detailed hydrogeologic mapping. (5) Drill and install wells with PVC casing and collect geologic, electromagnetic (induction), and gamma logs. (6) Conduct offshore-continuous seismic-reflection surveys to delineate the hydrogeologic deposits surrounding the study area.

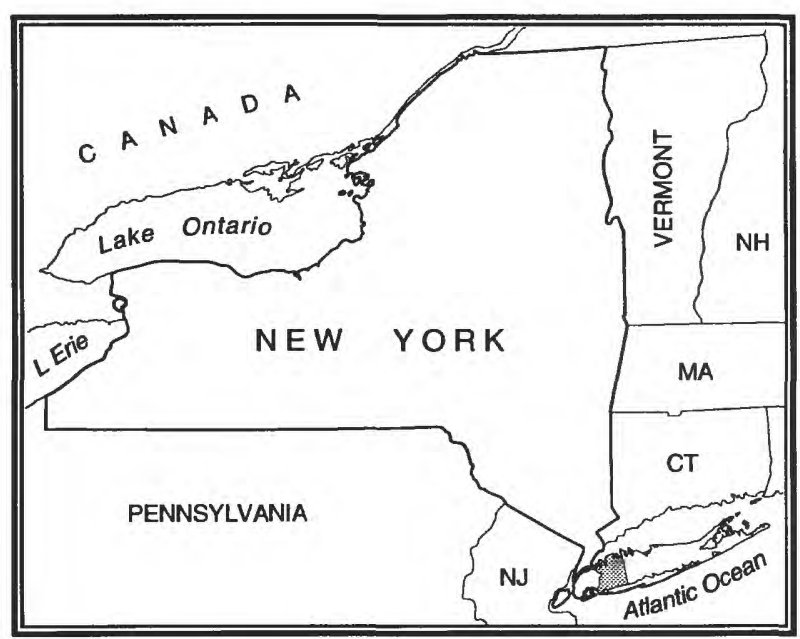

Progress and significant results: A monitoring network of 150 wells was developed and maintained; 19 observation wells were drilled and installed in the Great Neck peninsula; and 17 were drilled and installed in the Manhasset Neck peninsula.

Four distinct and separate saltwater wedges were delineated within the Great Neck peninsula. Several public-supply wells have been affected by these saltwater wedges. Borehole geophysical logging (gama and induction), filter press, and well-screen samples were used to delineate the saltwater interface in Great Neck. Several saltwater wedges were detected in Manhasset Neck and are being analyzed

Geologic data obtained from drilling indicate extensive erosion of Cretaceous deposits underlying Great Neck and Manhasset Neck. A previously undetected confined aquifer was found to underlie parts of the Great Neck peninsula, and appears to be in hydraulic contact with the Magothy aquifer to the south. Offshore seismicreflection surveys in the Great Neck vicinity provided new information on the extent and type of hydrogeologic deposits underlying Little Neck and Manhasset Bays and revealed several northwest-southeast trending buried valleys. These valleys appear to be at least 1 mile wide and over 20 feet deep and are infilled with silt and clay.

Plans for next year: Continuation of drilling and geophysical logging of observation wells in the Manhasset Neck Peninsula. Analysis of seismic-reflection, borehole geophysical , and hydraulic-head data. 


\section{Kings and Queens Aquifer (NY 92-203)}

Period of project: April 1992 through March 1996

Project leader: Henry F.H. Ku

Field location: Kings and Queens Counties

Cooperating agency: New York City Department of Environmental Protection

Problem: Public water supply in Kings and Queens Counties has historically been problematic. Early ground-water withdrawals caused severe water-level declines and saltwater intrusion, and urbanization resulted in ground water contamination. As a result, pumping was stopped in 1947 in Kings County and in 1974 in western Queens County; this cessation caused flooding of underground structures as water levels recovered. Most water is now supplied through aqueducts that tap upland reservoirs. Recent droughts have promoted renewed interests in tapping ground water for public supply.

Objectives: (1) Establish a data-collection network that includes ground-water levels and streamflow. (2) Define the ground-water quality with an emphasis on volatile organic compounds and saltwater intrusion. (3) Through numerical simulations, determine the feasibility of groundwater withdrawals while maintaining a workable balance among the following: (a) dewatering of underground structures, (b) effects on the position of the fresh-water-salt-water interface, and (c) minimizing the potential for drawing shallow contamination into the deeper aquifers.

Approach: Compile water-quality data from the past 10 years and from data obtained from about 100 wells used in a 1981-83 study. Establish stream-gaging stations at two locations. Drill 10 additional PVC wells and use Electromagnetic induction to determine vertical waterquality profiles. Identify long-term water-level monitoring network. Develop a detailed threedimensional ground-water flow model of western Long Island that will be calibrated to average, steady-state conditions, and test various pumping and dewatering scenarios.

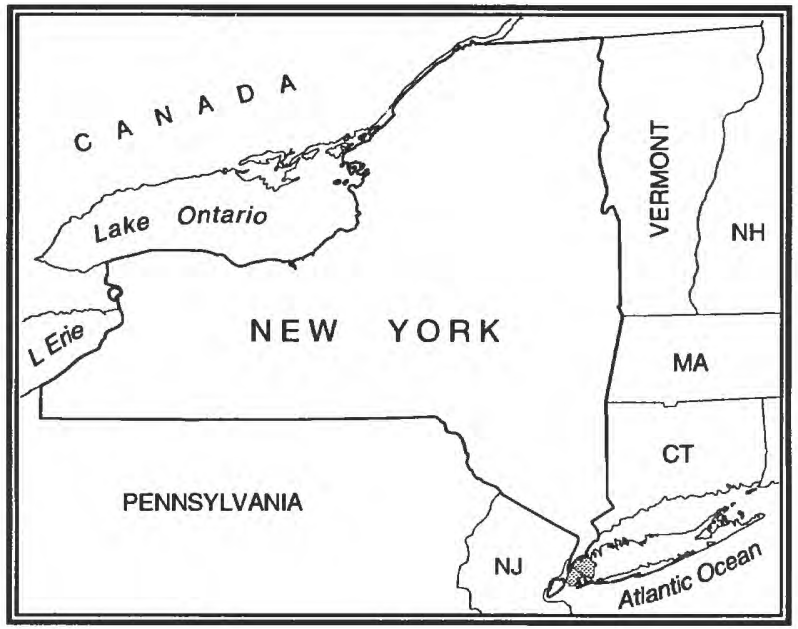

Progress and significant results: A well network was established and water-levels were measured monthly for 1 year and are now being measured quarterly . Continuous data loggers were installed at two surface-water data-collection sites. Water samples from 87 of the 106 wells in the 1983 study have been collected and analyzed. Twelve wells were installed to obtain water-level measurements, and drilling of 17 wells that will provide hydrogeologic information, and water-level and water-quality information began in September 1994.

Data necessary for numerical ground-waterflow-modeling have been prepared with a geographic information system (GIS). Preliminary model runs have been started.

Plans for next year: Continuous data collection at the two surface-water sites and quarterly water-level measurements will continue. When the 17 new wells are completed and logged, they, along with other wells not sampled during the earlier sampling phase, will be sampled for water-quality analysis. Updated information from the new wells will be incorporated into the model design. Historic and present waterquality data will be compiled and analyzed. The final reports will be written.

The ground-water flow model will be calibrated at several steady-state transient time periods. The results of calibrated modeling will be evaluated to establish uncertainty in the model's parameters, and predictive modeling of proposed pumping stresses (specified by the cooperator) will be simulated. A report about the ground-water flow model will be prepared. 


\section{Human Activities and Water QUALITY (NY 93-300)}

Period of project: October 1992 through September 1996

Project leader: Paul E. Misut

Field location: Nassau and Suffolk Counties

Cooperating agency: Suffolk County Water Authority

Problem: The chemical quality of Long Island's shallow ground water has been adversely affected by nonpoint-source contamination. Statistical models that identify potential sources of nonpointsource contamination in Nassau and Suffolk counties have been developed from data through a simple, fixed-radius method of delineating contributing areas to wells. Methods are needed that more accurately delineate contributing areas so that their effect on the predictions of these statistical models can be assessed. Once potential sources of contamination have been identified through statistical modeling, the aquifer systems that are most susceptible to contamination from human activities can be identified and protected.

Objectives: (1) To determine whether more complex methods of delineating contributing areas to a well improves correlations between contaminant presence and variables representing human activities and hydrogeologic conditions, and (2) to evaluate the transport and fate of human-derived contaminants as they migrate to deep parts of Long Island's aquifer system.

Approach: Water-quality data from 90 shallow observation wells in five representative land-use areas will be used to test the hypothesis that the relation between the presence or absence of a particular constituent, and variables representing human activities and hydrogeologic conditions, is independent of the size and shape of the contributing area used to quantify the explanatory variables. An attempt to improve the statistical significance of the models developed by the fixed-radius method will be made by quantifying explanatory variables in contributing areas defined by more sophisticated methods, which include (1) varying the size of a fixed radius, (2) using variable shapes, (3) analyti-

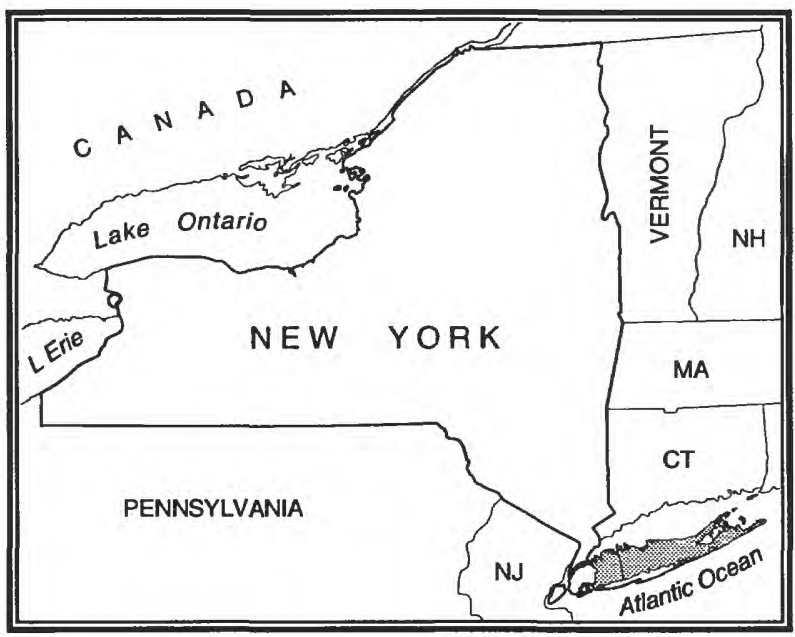

cal flow modeling, and (4) numerical flow/transport modeling. Results will identify which method provides the best correlations between water-quality data and the explanatory variables.

Concentrations of contaminants that are correlated with human activities in the study area will be examined along regional flow paths delineated by a two-dimensional ground-water flow model. Water-quality data acquired from newly installed and/or older wells along selected flow paths, and retrieval of historic water-quality data, will allow for the investigation of (1) the transport of selected contaminants along regional flow paths, (2) the approximate extent of nonpoint-source contamination migration within the aquifer system, and (3) the consistency of contaminant presence along flow paths relative to historical human activities within source areas. Changes in ground-water chemistry along regional flow paths resulting from geochemical processes will also be determined.

Progress and significant results: The statistical significance of models relating shallow groundwater quality to variables representing human activities and hydrogeologic conditions did not improve from use of more sophisticated techniques to delineate contaminant-contributing areas. This probably reflects the relative homogeneity of explanatory variables and hydrologic conditions in the vicinity of the 90-well network and indicates that, in similar hydrologic and land-use settings, the use of simple radial buffers adequately identifies potential sources of contamination to shallow observation wells.

Plans for next year: Inventory ground-water quality along regional ground-water flow paths; evaluate extent of contaminant migration along regional flow paths; and evaluate processes that affect the transport and fate of these contaminants. 


\section{Evaluation of the Hydrogeologic System at THE BrookHaVen National LABORATORY, LONG ISLAND (NY 94-301)}

Period of project: February 1994 through September 1996

\section{Project leader: Michael Scorca}

Field location: Central Suffolk County

\section{Cooperating agency: Brookhaven National Laboratory}

Problem: Onsite waste disposal at the Brookhaven National Laboratory (BNL) has resulted in the release of contaminants into the ground-water system. Although hydrogeologic data have been collected in several previous studies, current data are insufficient to select appropriate aquifer-remediation methods. A detailed investigation of the local system, as well as the regional geologic setting and hydrologic conditions, are required. Pleistocene-age clay layers complicate ground-water flow paths at the site. Detailed information on the underlying stratigraphy will enable improved delineation of ground-water flows and prediction of contaminant migration.

Objectives: (1) To assist BNL in the evaluation of the geologic setting and the local ground-water system at the site by defining the stratigraphy of aquifers and confining units. BNL will use this information in contaminant transport studies and to select appropriate aquifer-remediation techniques.

Approach: During the next 3 years, test-boring programs will be observed and previously col-

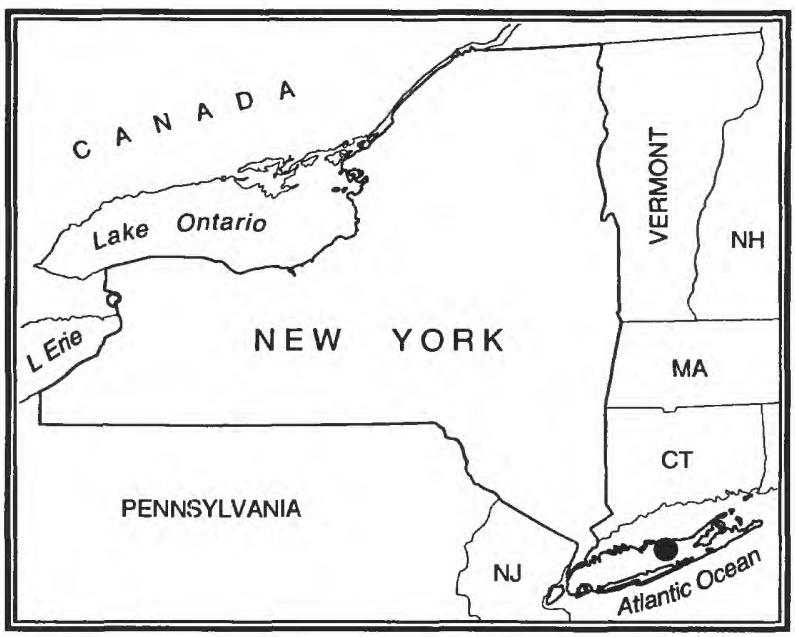

lected geologic samples will be examined. Water-level-measurement runs will be coordinated with BNL. Borehole-geophysical logging and analysis will be conducted at selected wells onsite and offsite to define subsurface stratigraphy. The USGS will provide technical advice on modeling methods, and will review and evaluate ground-water models and case studies developed by BNL consultants.

Progress and significant results: Published reports, maps, database, and cores were researched. Old and new core samples were examined by microscope. The sparsity of historical data from three previous investigations allows differing interpretations. Drilling sites were visited during two drilling programs to identify geologic units. A unit similar to Gardiners Clay is present in the southeast part of BNL, but apparently has been eroded in the south-central area. Water levels were collected during the fall of 1994 and Spring of 1995.

Plans for next year: To observe drilling as needed. To help locate and transfer USGS ground-water level and water-quality data to BNL in hard copy and electronic formats and compile data received from BNL and enter into hard-copy and electronic data bases. 


\section{Determination of Ground-Water Discharge to the Peconic Estuary System, EAstern Long IsLaNd, New YORK (NY 94-302)}

Period of project: October 1993 through

Project leader: Christopher E. Schubert

Field location: North Fork, Shelter Island, and South Fork areas of eastern Suffolk County

Cooperating agency: Suffolk County Department of Health Services

Problem: The Peconic estuary system has been plagued with an unusual algal bloom since 1985 . Adverse effects of the algal bloom, popularly called "brown tide," include the severe decline of major shellfisheries, and a sharp reduction in the extent of Peconic estuary eelgrass beds, which provide critical habitat for commercially important finfish as well as shellfish. The Brown Tide Comprehensive Assessment and Management Program (BTCAMP), initiated by Suffolk County Department of Health Services in 1988, has identified ground-water discharge to the Peconic River and Flanders Bay, at the head of the estuary, as a significant control on surfacewater chemistry in the western, most stressed part of the estuary. With the recent inclusion of the Peconic estuary system in the National Estuary Program, one of the core activities of the Peconic Estuary Program, under the coordination of Suffolk County Department of Health Services, is to improve estimates of ground-water discharge to the Peconic Estuary system.

Objectives: To provide data on ground-water discharge to the Peconic Estuary system for use in estuarine surface-water modeling and management-alternative evaluations, conduct sitespecific ground-water investigations for use in development of watershed-management efforts, and provide technical assistance to the Peconic

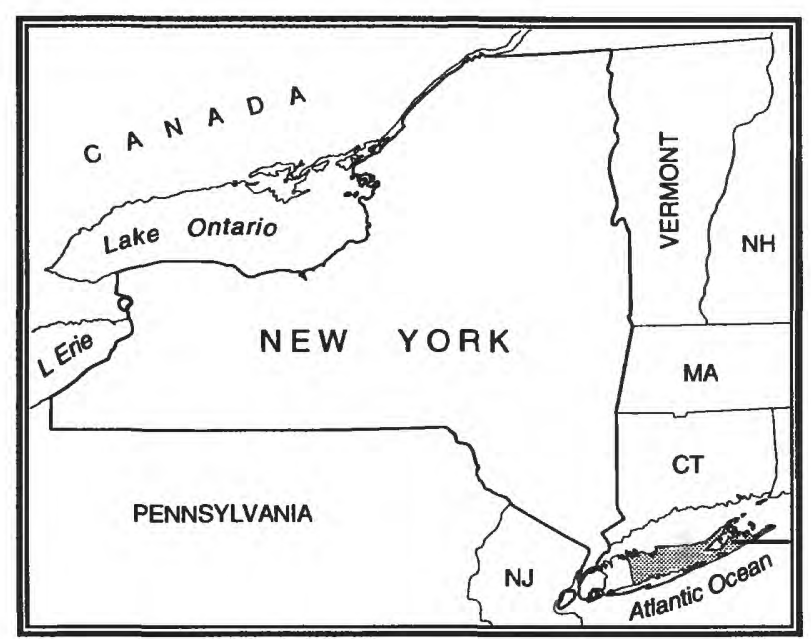

Estuary Program in interpreting ground-water information.

Approach: (1) To conduct a regional waterbudget analysis that evaluates ground-water flow boundaries along subwatershed segments to provide computations of the magnitude and distribution of ground-water discharge. (2) To develop site-specific, cross-sectional, groundwater-flow models to assess patterns and rates of ground-water movement.

Progress and significant results: An inventory of ground-water information, initial delineation of sub-watershed ground-water divides, and compilation of ground-water-level data for the regional water budget analysis were completed, as were collection of two sets of quarterly ground-water level measurements, installation of 41 observation wells, initiation of boreholegeophysical surveys of new wells, and preliminary simulation of ground-water flow for the site-specific investigations.

Plans for next year: To conduct water-tablecontour mapping, revise delineations of subwatershed ground-water divides, and evaluate water-budget components for the regional waterbudget analysis. To complete installation and borehole-geophysical surveys of remaining observations wells, continue collection of quarterly ground-water-level measurements, and continue simulation of ground-water flow for the site-specific investigations. 


\section{National Water-Quality Assessment OF THE LONG ISLAND-NEW JERSEY Coastal Drainages (NY 94-305)}

Period of project: October 1993 through September 1998

Project leader: Paul E. Stackelberg and Stephen A. Terraciano

Field location: Coastal drainages in New York and New Jersey

Cooperating agency: Federally funded

Problem: Long-term, nationwide, multiscale, interagency, interdisciplinary studies concerning the status of the Nation's surface-water and ground-water resources are needed to provide sound scientific information that can be used to establish policies to protect and enhance the quality of the Nations's water resources.

Objectives: (1) To describe the quality of the nation's surface-water and ground-water resources. (2) To detect trends (or lack of trends) in water quality, and (3) To identify the principal natural and human-derived factors that affect the quality of these water resources.

Approach: The Long Island-New Jersey Coastal drainages study unit is one of 60 study units across the Nation that are designed to provide water-quality information on a local and regional scale. Information provided from all 60 study units will be compiled for regional and national assessments of priority water-quality issues. Initial activities within the study unit will include compilation and analysis of available

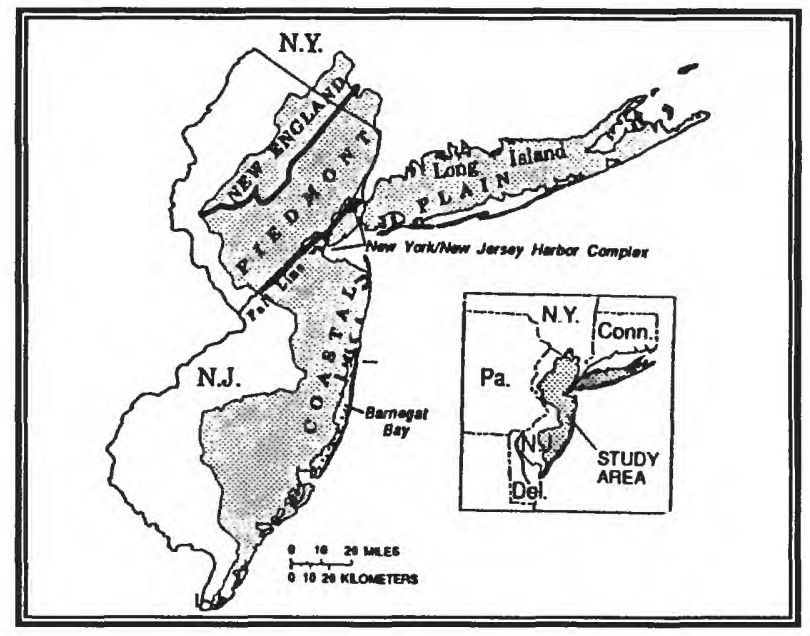

data to identify historical water-quality patterns and priority issues within the study area, and to formulate study designs. Intensive data collections will occur during 1996-98 to identify spatial and temporal patterns in surface-water and ground-water resources and biological communities. A liaison committee composed of affiliates from Federal, State, local university, private, and citizen groups with water-resources responsibilities will be developed to help (1) coordinate data and work tasks, (2) review plans and results, and (3) guide the study unit toward appropriate efforts.

Progress and significant results: The liaison committee met during 1994 to identify waterquality issues of highest priority within the study unit. Water-quality and biological data bases identified by the liaison committee are currently being compiled for analysis.

Plans for next year: Develop a consensus list of priorities for data analysis and develop a strategy to define the primary strata that control water quality in the study area. 
District Chief

Associate District Chief

Assistant District Chief for Informations Management Hydrologic Surveillance and Investigations Section Information Management Section Potsdam Field Office

Assistant District Chief for Scientific Investigations and Research

National Water Quality Assessment Program Watersheds Research Section

Administrative Services Unit, Chief

Coram Subdistrict Office Chief

Assistant Subdistrict Chief

Environmental and Hydrologic Investigations Section Hydrologic Surveillance and Analysis Section

Ithaca Subdistrict Office Chief

Environmental and Hydrologic Investigations Section Hydrologic Surveillance and Analysis Section
L. Grady Moore

Ward O. Freeman

Ward O. Freeman

Elizabeth A. Flanary Vacant

Howard C. Lent

Vacant

Patrick J. Phillips Stephen W. Wolcott

Cheryl M. Music

Vacant

Bronius Nemickas

Vacant

Vacant

Edward Bugliosi

Vacant

John Hornlein 


\section{REPORTS PUBLISHED OR RELEASED October 1992-September 1994}

\section{Reports Released in Fiscal Year ‘93}

\section{Project 200}

Baevsky, Y.H., 1992, Development of a digital data base to support water-quality modeling in small watersheds, [abst.] in USGS 7th annual Northeast ARC/ INFO Users Group Conference: Stamford, Conn., unpaginated.

\section{Project 178}

Butch, G. K., 1993, Estimating bridge scour in New York from historical U.S. Geological Survey streamflow measurements in Shen, H. W., Su, S. T., and Wen, F., eds., Hydraulic Engineering '93, Proceedings of the 1993 Conference: San Francisco, Ca., July 25-30,1993, v. 2, p. 1866-1871.

- 1993, Relation of local scour to hydraulic properties at selected bridges in New York in Shen, H. W., Su, S. T., and Wen, F., eds., Hydraulic Engineering '93, Proceedings of the 1993 Conference: San Francisco, Ca., July 25-30,1993, v. 2, p. 1872-1875.

\section{Project 160}

Buxton, H, T., and Modica, Edward, 1992, Patterns and rates of ground-water flow on Long Island, New York: Ground Water, v. 30, no. 6, p. 857-866.

\section{Project 888}

Cohen, Andrew., 1992, U.S. Geological Survey's National Water Information System Data Base, [abst.] in USGS 7th annual Northeast ARC/INFO Users Group Conference: Stamford, Conn., unpaginated.

\section{Project 186}

Eckhardt, D.A., Wagenet, R. J., and Barnes, P. L., 1992, Soil-water hydraulic models for unit-gradient drainage in a layered silt-loam, [abst.] in Agronomy Abstracts, 1992 Annual Meetings, November 1-6, 1992: Minneapolis, MN., p. 213.

- 1993, Fate of alachlor, atrazine, and desethylatrazine in a corn plot near Topeka, Kansas, [abst.] in Conference on Agricultural Research to Protect Water Quality: Soil and Water Conservation Society, February 22-24, 1993, Minneapolis, MN., unpaginated.

\section{Project 045}

Embree, W. N., 1993, Water level control in the New York State Canal System within the Oswego River basin-Description of control points and guidelines to their operation: New York State Thruway Authority
Canal Corporation Technical Manual 900-0-02, 35 p.

Project 159.

Feldman, S. M., Smolensky, D. A., Masterson, J. P., 1992, Ground-water quality in the BethpageHicksville-Levittown area, Long Island, New York, with emphasis on volatile organic compounds: U.S. Geological Survey Water-Resources Investigations Report 90-4182, $51 \mathrm{p}$.

\section{Project 199}

Freehafer, Douglas., 1992, Delineation of drainage basins in a large watershed by digital elevation model: [abst.] in USGS 7th annual Northeast ARC/ INFO Users Group Conference, Stamford, Conn., unpaginated.

\section{Project 156}

Heisig, P.M., and Prince, K.R., 1993, Characteristics of a ground-water plume derived from artificial recharge with reclaimed wastewater at East Meadow, Long Island, New York: U.S. Geological Survey Water-Resources Investigations Report 91-4118, 52 p.

\section{Project 157}

Ku, H.F.H. and Aaronson, D.B., 1992, Rates of water movement through the floors of selected stormwater basins in Nassau County, New York: U.S. Geological Survey Water-Resources Investigations Report 914012, $121 \mathrm{p}$.

\section{Project 208}

Lawrence, G.B., David, M.B., and Shortle, W.C., 1992, Speciation of soil and soil-solution aluminum in Red Spruce stands receiving acidic deposition [abst.], in Agronomy Abstracts, 1992 Annual Meetings, November 1-6, 1992: Minneapolis, MN., p. 350-351.

\section{Project 088}

Lawrence, G.B. and Fernandez, I. J., 1993, A reassessment of areal variability of throughfall deposition, in Ecological Applications, Geological Society of America, v. 3, no. 3, p. 473-480.

\section{Project 111}

LeaMond, Haefner, Cauller, Stackelberg, Groundwater quality in five areas of differing land use in Nassau and Suffolk Counties, New York, 1987-88: U.S. Geological Survey Open-File Report 91-180, 67 p.

\section{Project 045}

Lumia, R. and Murray, P. M., 199?Maximum known stages and discharges of New York streams, 18651989 , with descriptions of five selected floods, 1913- 


\section{REPORTS PUBLISHED OR RELEASED \\ October 1992-September 1994 (continued)}

85: U.S. Geological Survey Water-Resources Investigations Report 92-4042,? p.

Project 888

Marshall, M.P., 1992, Water-Resources Programs in the New York District-Fiscal Years 1990-92: U.S. Geological Survey Open-File Report 92-473, 67 p.

\section{Project 172}

McNew-Cartwright, E.R., 1992, A nonlinear regression application to ground-water-flow modeling in a shallow coastal aquifer on Long Island, New York [abst.], in EOS Transactions: American Geophysical Union, 1992 fall meeting, v. 73, no. 43, October 27, 1992, Supplement H51D-7, p. 229.

\section{Project 187}

McPherson, W. S.,1993, Hydrogeology of unconsolidated deposits in Chenango County, New York: U.S. Geological Survey Water-Resources Investigations Report 91-4138, 43 p.

\section{Project 114}

Miller, T.S. and Sherwood, D.A., 1993, Geohydrology and water quality of the Sand Ridge glacial drift aquifer in Oswego County, New York: U.S. Geological Survey Water-Resources Investigations Report 914042, 31 p.

\section{Project 193}

Misut, P.E. and Feldman, S.M., 1993, Effects of localscale Hydrogeologic Features on particle-tracking analysis of ground-water flow at Patchogue, Long Island, New York, in Eckstein, E. and Zaporozec, A., eds., Hydrogeologic investigations and monitoring ground water modeling, Proceedings of industrial and agricultural impacts on the hydrologic environment: American Institute of Hydrology, May 16-20, 1993, Washington, D.C., p. 193-206.

\section{Project 152}

Murdoch, P.S., and Stoddard, J.L., 1992, The role of nitrate in the acidification of streams in the Catskill Mountains of New York: Water Resources Research, v. 28 , no. 10 , p. $2707-2720$.

\section{Project 199}

Phillips, P. J., Kendall, C., and Bachman, L. J., 1993, Use of deuterium and oxygen-18 to trace groundwater/surface-water interaction in a seasonal pond setting [abst.], in 1993 Spring Meeting, American Geophysical Union, May 24-28, 1993, Baltimore MD.: EOS Transactions, v. 74, no. 16, April 20, Supplement, p. 140.
Project 170

Sanford, W.E., Surface, J.M., Steenhuis, T.S., and Peverly, J.H., 1992, Flow characteristics of landfill leachate through rock-reed filters, [abst.], in Programs and abstracts, Global Wetlands-Old world and New-Intecol's IV International Wetlands Conference: September 13-18, 1992, Columbus, Ohio, p. 85.

\section{Project 167}

Snow, R.F., and Wolcott, S.W., 1992, Estimated thickness and potential well yield of stratified-drift deposits in selected areas in northern Westchester County, New York: U.S. Geological Survey Water Resources Investigations Report 91-4030, 6 plates, scale 1:24,000.

\section{Project 177}

Stackelberg, P.E. and Siwiec, S.W., 199 Evaluation of statistical models to predict chemical quality of shallow ground water in the Pine Barrens of Suffolk County, Long Island, New York: U.S. Geological Survey Water-Resources Investigations Report 924100,26 p.

\section{Project 202}

Stumm, Frederick, 1993, Use of focused electromagnetic-induction borehole geophysics to delineate the saltwater-freshwater interface in Great Neck, Long Island, New York, in Bell, R.S. and Lepper, C.M., eds., Proceedings of the symposium on the application of geophysics to engineering and environmental Problems: April 18-22, 1993, San Diego, California, v. 2, p. 513-525

\section{Project 170}

Surface, J.M., Peverly, J.H., Steenhuis, T.S., Sanford, W.E., 1992, Landfill leachate treatment by means of a constructed wetland [abst.], in Programs and abstracts, Global Wetlands-Old World and NewIntecol's IV International Wetlands Conference: September 13-18, 1992, Columbus, Ohio, p. 102.

Weigel, J.F., 1993, Selected data on water quality and bottom material of New York streams, 1987-88: U.S. Geological Survey Open-File Report 92-476, 250 p.

\section{Project 116}

Yager, R. M., 1993, Estimation of hydraulic conductivity of a riverbed and aquifer system on the Susquehanna River in Broome County, New York: U.S. Geological Survey Water Supply Paper 2387, 49 p.

Project 176

Zarriello, P. J., 1993, Determination of the contribut- 


\section{REPORTS PUBLISHED OR RELEASED \\ October 1992-September 1994 \\ (continued)}

ing area to six municipal ground-water supplies in the Tug Hill glacial aquifer of northern New York, with emphasis on the Lacona-Sandy Creek well field: U.S. Geological Survey Water-Resources Investigations Report 90-4145, 51 p.

\section{Reports Released in Fiscal Year ‘94}

Project 152

Baldigo, B. P., 1993, Response of brook-trout (Salvalinus fontinalis) populations to acidification of streams in the Catskill Mountains, New York, USA, in Ecotoxicology and Environmental Chemistry-a Global Perspective, Abstract Book : First SETAC World Congress, March 28-31, 1993, Lisbon, Portugal, p. 257, no. 300 .

Brown, C.J., and Schoonen, M.A.A., 1994, Iron reactions in the Magothy and Upper Glacial aquifers of Nassau and Suffolk Counties, Long Island, New York, in Geology of Long Island and Metropolitan New York, Programs with Abstracts: April 23, 1994, State University of New York at Stony Brook, N.Y., p. 9-15.

\section{Project 200}

Burns, D.A., Murdoch, P.S., and Lawrence, G.B., 1993, Effects of ground water seeps in $\mathrm{NO}_{3}$ - concentrations in stream water in the Catskill Mountains of New York, in EOS Transactions, American Geophysical Union, 1993 Fall Meeting v. 74, no. 43, October 26, 1993/Supplement, p. 258.

\section{Project 178}

Butch, G. K. and Lumia, Richard, 1994,. Effects of flow duration on local scour at bridge piers in New York, in Hydraulic Engineering '94, Volume 1: Proceedings of the American Society of Civil Engineers 1994 Conference, Aug 1-5, 1994, Buffalo, N. Y., p. 46-50.

Project 140

Coon, W. F., 1994, Design of Manning's-roughness coefficient study in New York State, in Hydraulic Engineering '94, Volume 1: Proceedings of the American Society of Civil Engineers 1994 Conference, August 1-5, 1994, Buffalo, N. Y., p. 677-681.

-1994, Roughness coefficients for high-gradient channels in New York State in Hydraulic Engineering '94, Volume 1: Proceedings of the American Society of Civil Engineers 1994 Conference , Aug 1-5, 1994, Buffalo, New York, p. 722-726.

Project 208

David, M.B., Lawrence, G.B., and Shortle, W., 1993, Ca and A1 chemistry of soils and soil solution in northeastern Red Spruce stands, in Agronomy Abstracts, 1993 Annual Meeting: November 7-12, 1993, Cincinnati, Ohio, p. 334.

\section{Project 088}

Fernandez, I.J., Rustad, L.E., and Lawrence, G.B., 1993, Estimating total mass, nutrient content, and trace metals in soils under a low elevation spruce-fir forest: Canadian Journal of Soil Science, v. 73, no. 8, p. 317-328.

\section{Project 171}

Heisig, P. M., 1994, Generalized stratigraphy, surficial geology, types of aquifers, and 1988-89 ground-water pumpage in Eastern Saratoga County, New York: U.S. Geological Survey Water -Resources Investigations Report 93-4029, 16 p.

\section{Project 156}

Heisig, P. M., 1994, Local point sources that affect ground-water quality in the East Meadow area, Long Island, New York: U.S. Geological Survey WaterResources Investigations Report 92-4038, 28 p.

Project 155

Johnston, W.H. and Sherwood, D.A., 1994, Waterresources of Monroe County, New York, water years 1984-88, with emphasis on water quality in the Irondequoit Creek basin: U.S. Geological Survey Open File Report 93-370, 311 p.

Project 205

Kappel, W. M., 1994a, Mudboils and mudslides in the Tully Valley near Syracuse, New York, in Geological Society of America, Abstracts with Programs: March 28-30, 1994, Binghamton, N.Y., v. 26, no. 3, p. 28, no. 03021.

-1994b, The U.S. Geological Survey-A source of water resources data, in Iroquois Environmental Newsletter: spring 1994, Issue 3, p. 13-14.

\section{Project 164}

Kappel, W. M. and Tepper, D.H., 1993, An overview of the recent U.S. Geological Survey Study of the Hydrogeology of the Niagara Falls area of New York, in Proceedings Modern Trends in Hydrogeology 1992: Conference of the Canadian National Chapter, International Association of Hydrogeologists, May 11-13, 1992, Hamilton, Ontario, Canada, p. 609-622.

Project 208

Lawrence, G.B. and David, M.B., 1993, Method for 


\section{REPORTS PUBLISHED OR RELEASED October 1992-September 1994 (continued)}

chemical evaluation of soil solution in northeastern Red Spruce stands, in Agronomy Abstracts, 1993 Annual Meeting: November 7-12, 1993, Cincinnati, Ohio, p. 337.

Project 201

McPherson, W.S., and Miller, T.S., 1994, Distribution and thickness of unconsolidated deposits in Schuyler County, New York: U.S. Geological Survey WaterResources Investigations Report 93-4004, 2 pl, scale 1:24,000.

Miller, T.S., 1993, Glacial geology and the origin and distribution of aquifers at the valley heads moraine in the Virgil Creek and Dryden Lake-Harford Valleys, Tompkins and Cortland Counties, New York: U.S. Geological Survey Water-Resources Investigations Report 90-4168, 34 p.

\section{Project 152}

Murdoch, P.S. and Stoddard, J.L., 1993, Chemical characteristics and temporal trends in eight streams of the Catskill Mountains, New York: Water, Air, \& Soil Pollution, v. 67, nos. 3-4, p. 367-395.

\section{Project 199}

Murray, K.R., and Freeman, W.O., 1994, Water quality in the Hudson River basin-Working together to solve the puzzle: U.S. Geological Survey Open-File Report 94-90, 3 p.

\section{Project 240}

Schubert, C.E., and Busciolano, R, 1994, Peak stormtide elevations produced by the December 1992 storm along the coast of Long Island, New York with historical peak storm-tide elevations, in Programs with Abstracts, Geology of Long Island and Metropolitan New York: April 23, 1994, SUNY, Stony Brook, N.Y., p.130-136.

\section{Project 180}

Stackelberg, P.E., 1993, Use of a statistical model and a geographic information system to evaluate the effect of land use on the quality of shallow ground water on Long Island, New York [abst.], in First International Conference /Workshop on Integrating Geographic Information Systems and Environmental Modeling, September 15-19, 1991, Boulder, Co. [unpaginated].

Project 202

Stumm, F., 1993, Delineation of three areas of saltwater intrusion within the Great Neck Peninsula, Long Island, New York [abst.] in Abstracts with Programs: Geological Society of America, 1993 Annual Meeting;
October 25-28, 1993, Boston, Mass., v. 25, no. 6, p. A291-A-292.

Project 202

Stumm, Frederick and Lange, A. D., 1994, Delineation of the hydrologic framework and extent of saltwater intrusion within the Great Neck Peninsula, Long island, New York, in Programs with Abstracts, Geology of Long Island and Metropolitan New York: April 23, 1994, State University of New York at Stony Brook, N.Y., p. 140-146.

Project 170

Surface, J. M., Peverly, J. H., Steenhuis, T. S., Sanford, W. E., 1993, Effect of season, substrate composition, and landfill-leachate treatment in a constructed wetland, in Moshiri, G.A., ed., Constructed Wetlands for Water Quality Improvement: October 21-24, 1991, Boca Raton, Fl., Lewis Publishers, p. 461-472.

-1994, Effect of season and substrate composition on landfill leachate treatment in a constructed wetland: The Information Exchange, winter 1994, v. 4, no. 1, p. 7-9.

\section{Project 175}

Weiss, L. A., Schaffranek, R. W., and DeVries, M. P., 1994, Flow and chloride transport in the tidal Hudson River, New York in Hydraulic Engineering '94, Volume 2: Proceedings of the American Society of Civil Engineers 1994 Conference, Aug 1-5, 1994 , Buffalo, N. Y., p. 1300-1305.

\section{Project 888}

Williams, J. H., Lapham, W. W., and Barringer, T. H., 1993, Application of electromagnetic logging to contamination investigations in glacial sand-andgravel aquifers: Groundwater Monitoring Review, v. xiii, no. 3, Summer 1993, p. 129-138.

\section{Project 161}

Zarriello, P. J. and Sherwood, D. A., 1993, Effects of stormwater detention on the chemical quality of runoff from a small residential development, Monroe County, New York: U.S. Geological Survey WaterResources Investigations Report 92-4003, 57 p. 


\title{
SOURCES OF U.S. GEOLOGICAL SURVEY PUBLICATIONS
}

Current releases are described in a monthly pamphlet, "New Publications of the Geological Survey." To receive this publication monthly, write to

\author{
U.S. Geological Survey \\ 582 National Center \\ Reston, VA 22092
}

Professional Papers, Bulletins, Water Supply Papers, Techniques of Water Resources Investigations may be purchased as paper or microfiche copies from

U. S. Geological Survey

ESIC-Open-File Reports Section

P.O. BOX 25286

Denver, CO 80225

Map, benchmark, and aerial-photograph information is available from

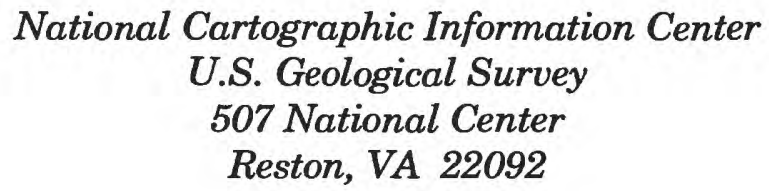

Requests for miscellaneous water information and information on water-resources programs in other States may be referred to

\author{
U.S. Geological Survey \\ Water Resources Division \\ 440 National Center \\ Reston, VA 22092
}

The Geological Survey National Center maintains a library with an extensive earth-sciences collection. Local libraries may obtain books, periodicals, and maps through interlibrary loan by writing to

\author{
U.S. Geological Survey Library \\ 950 National Center \\ Reston, VA 22092
}




\title{
ADDITIONAL SOURCES OF INFORMATION \\ ON PROGRAMS IN NEW YORK
}

\author{
WATER \\ District Chief \\ U.S. Geological Survey \\ 425 Jordan Road \\ Troy, NY 12180 \\ Phone: (518) 285-5695 \\ National MapPing \\ National Cartographic \\ Information Center \\ U.S. Geological Survey \\ 507 National Center \\ Reston, VA 22092 \\ Phone: (703) 860-6045
}

\section{GeOLOGY}

Geologic Inquiries Group

U.S. Geological Survey

907 National Center

Reston, VA 22092

Phone: (703) 648-4383

General InFormation

Public Inquiries Office

U.S. Geological Survey

503 National Center, Room 1C402

Reston, VA 22092

Phone: (703) 648-6892 